NBER WORKING PAPER SERIES

\title{
NARRATIVE ECONOMICS
}

Robert J. Shiller

Working Paper 23075

http://www.nber.org/papers/w23075

\author{
NATIONAL BUREAU OF ECONOMIC RESEARCH \\ 1050 Massachusetts Avenue \\ Cambridge, MA 02138 \\ January 2017
}

Presidential address delivered at the 129th annual meeting of the American Economic Association, January 7, 2017, Chicago, IL. The author declares no relevant conflicts of interest. The author thanks participants in seminars at which earlier versions of this address were presented, at the Bank of England, at the Toulouse School of Economics/Toulouse Institute of Advanced Studies, and at the Yale University Department of Economics. Special thanks go to George Akerlof, Bruno Biais, Jean-François Bonnefon, Michael Bordo, Donald Cox, Peter Dougherty, William Goetzmann, Dasol Kim, Rachel Kranton, Terry Loebs, Ramsay MacMullen, Peter Rousseau, Paul Seabright, Benjamin Shiller, Virginia Shiller, and Peter Temin. Research assistance was provided by Andrew Brod, Laurie Cameron Craighead and Nicholas Werle. The views expressed herein are those of the author and do not necessarily reflect the views of the National Bureau of Economic Research.

The author has disclosed a financial relationship of potential relevance for this research. Further information is available online at http://www.nber.org/papers/w23075.ack

NBER working papers are circulated for discussion and comment purposes. They have not been peer-reviewed or been subject to the review by the NBER Board of Directors that accompanies official NBER publications.

(C) 2017 by Robert J. Shiller. All rights reserved. Short sections of text, not to exceed two paragraphs, may be quoted without explicit permission provided that full credit, including () notice, is given to the source. 
Narrative Economics

Robert J. Shiller

NBER Working Paper No. 23075

January 2017

JEL No. E00,E03,E30,G02,N1

\section{$\underline{\text { ABSTRACT }}$}

This address considers the epidemiology of narratives relevant to economic fluctuations. The human brain has always been highly tuned towards narratives, whether factual or not, to justify ongoing actions, even such basic actions as spending and investing. Stories motivate and connect activities to deeply felt values and needs. Narratives "go viral" and spread far, even worldwide, with economic impact. The 1920-21 Depression, the Great Depression of the 1930s, the so-called "Great Recession" of 2007-9 and the contentious political-economic situation of today, are considered as the results of the popular narratives of their respective times. Though these narratives are deeply human phenomena that are difficult to study in a scientific manner, quantitative analysis may help us gain a better understanding of these epidemics in the future.

Robert J. Shiller

Yale University, Cowles Foundation

Box 208281

30 Hillhouse Avenue

New Haven, CT 06520-8281

and NBER

robert.shiller@yale.edu 


\section{Introduction}

By narrative economics I mean the study of the spread and dynamics of popular narratives, the stories, particularly those of human interest and emotion, and how these change through time, to understand economic fluctuations. A recession, for example, is a time when many people have decided to spend less, to make do for now with that old furniture instead of buying new, or to postpone starting a new business, to postpone hiring new help in an existing business, or to express support for fiscally conservative government. They might make any of these decisions in reaction to the recession itself (that's feedback), but to understand why a recession even started, we need more than a theory of feedback. We have to consider the possibility that sometimes the dominant reason why a recession is severe is related to the prevalence and vividness of certain stories, not the purely economic feedback or multipliers that economists love to model.

The field of economics should be expanded to include serious quantitative study of changing popular narratives. To my knowledge, there has been no controlled experiment to prove the importance of changing narratives in causing economic fluctuations. We cannot easily prove that any association between changing narratives and economic outcomes is not all reverse causality, from the outcomes to the narratives. But there have been true controlled experiments showing that people respond strongly to narratives, in the fields of marketing (Escalas 2007); journalism (Machill et al. 2007 ); education (McQuiggan et al. 2008); health interventions (Slater et al. 2003); and philanthropy (Weber et al. 2006).

My goal in this paper is to describe what we know about narratives and the penchant of the human mind to be engaged by them, to consider reasons to expect that narratives might well be thought of as important, largely exogenous shocks to the aggregate economy. This address extends some earlier work I have done with George Akerlof (Akerlof and Shiller, 2009, 2015) and some of my own earlier work going back decades (Shiller 1984), but develops the analysis and captures a much broader relevant literature.

Of course, almost nothing beyond spots on the sun is truly exogenous in economics, but new narratives may be regarded often as causative innovations, since each narrative originates in the mind of a 
single individual (or a collaboration among a few). Joel Mokyr (2016) calls such an individual a "cultural entrepreneur," and traces the concept back to David Hume (1742) who wrote that "what depends on a few persons is, in great measure, to be ascribed to chance, or secret and unknown causes; what arises from a great number may often be accounted for by determinate and known causes."

I will present here some thoughts on these effects of a "few persons" and offer a class of mathematical models for some of these determinate and known causes of the path of narratives, quantifying the dynamics of narratives, and will consider how our understanding can be enhanced of major economic events: the Depression of 1920-21, the Great Depression of the 1930s, the Great Recession of 2007-2009, and our present time right after our narrative-filled 2016 presidential election.

I use the term narrative to mean a simple story or easily expressed explanation of events that many people want to bring up in conversation or on news or social media because it can be used to stimulate the concerns or emotions of others, and/or because it appears to advance self-interest. To be stimulating, it usually has some human interest either direct or implied. As I (and many others) use the term, a narrative is a gem for conversation, and may take the form of an extraordinary or heroic tale or even a joke. It is not generally a researched story, and may have glaring holes, as in "urban legends." The form of the narrative varies through time and across tellings, but maintains a core contagious element, in the forms that are successful in spreading. Why an element is contagious, when it may even "go viral," may be hard to understand, unless we reflect carefully on the reason people like to spread the narrative. Mutations in narratives spring up randomly, just as in organisms in evolutionary biology, and when they are contagious, the mutated narratives generate seemingly unpredictable changes in the economy.

Narratives can be based on varying degrees of truth. Wishful thinking may enhance contagion (Benabou 2013). The impact of non-factual narratives might be somewhat greater in today's world than in decades past, since established news media are in upheaval after the relatively recent advent of modern

\footnotetext{
${ }^{1}$ Hume (1788) XIV p. 101.
} 
information technology and social media. But in past decades we can also observe that narratives with no factual basis were widely disseminated and believed. For instance, until modern times, it was asserted that women were not capable of learning men's occupations (Goldin 2014). Similarly, it was argued that some racial or ethnic groups were not really capable of integrating into civilized society (Myrdal, 1974). How people could believe these views in the past seems hard to imagine today because we are no longer immersed in their narratives.

Disturbingly, the Oxford Dictionary in 2016 gave "post-truth" as "international word of the year." Are narratives becoming increasingly based on false ideas? This possibility is something we ought to try to understand better. Among normal people, narratives are often somewhat dishonest and manipulative. In a competitive market where competitors manipulate customers and profit margins have been competed away to normal levels, no one company can choose not to engage in similar manipulations. If they tried, they might be forced into bankruptcy. A phishing equilibrium with a certain equilibrium acceptable level of dishonesty in narrative is established (Akerlof and Shiller, 2015).

\section{The Role of Narratives Broadly, in the Social Sciences and the Humanities}

When we as economists want to understand the most significant economic events in our history, such as the Great Depression of the 1930's, or subsequent recessions, or policies towards wealth and poverty, we rarely focus on the important narratives that accompanied them. We have lagged behind other disciplines in attending to the importance of narratives (Figure 1), and while all disciplines use narratives more since 2010, economics (and finance) remain laggards. This is despite calls for economists' attention to “social dynamics" and "popular models" (Shiller 1984); to a new "culturnomics” (Michele 2005); or "humanomics" (McCloskey 2016); or for more "narrativeness" in economics (Morson and Schapiro 2017). We see little use of enormous databases of written word that might be used to study narratives.

\footnotetext{
${ }^{2}$ https://en.oxforddictionaries.com/word-of-the-year/word-of-the-year-2016
} 


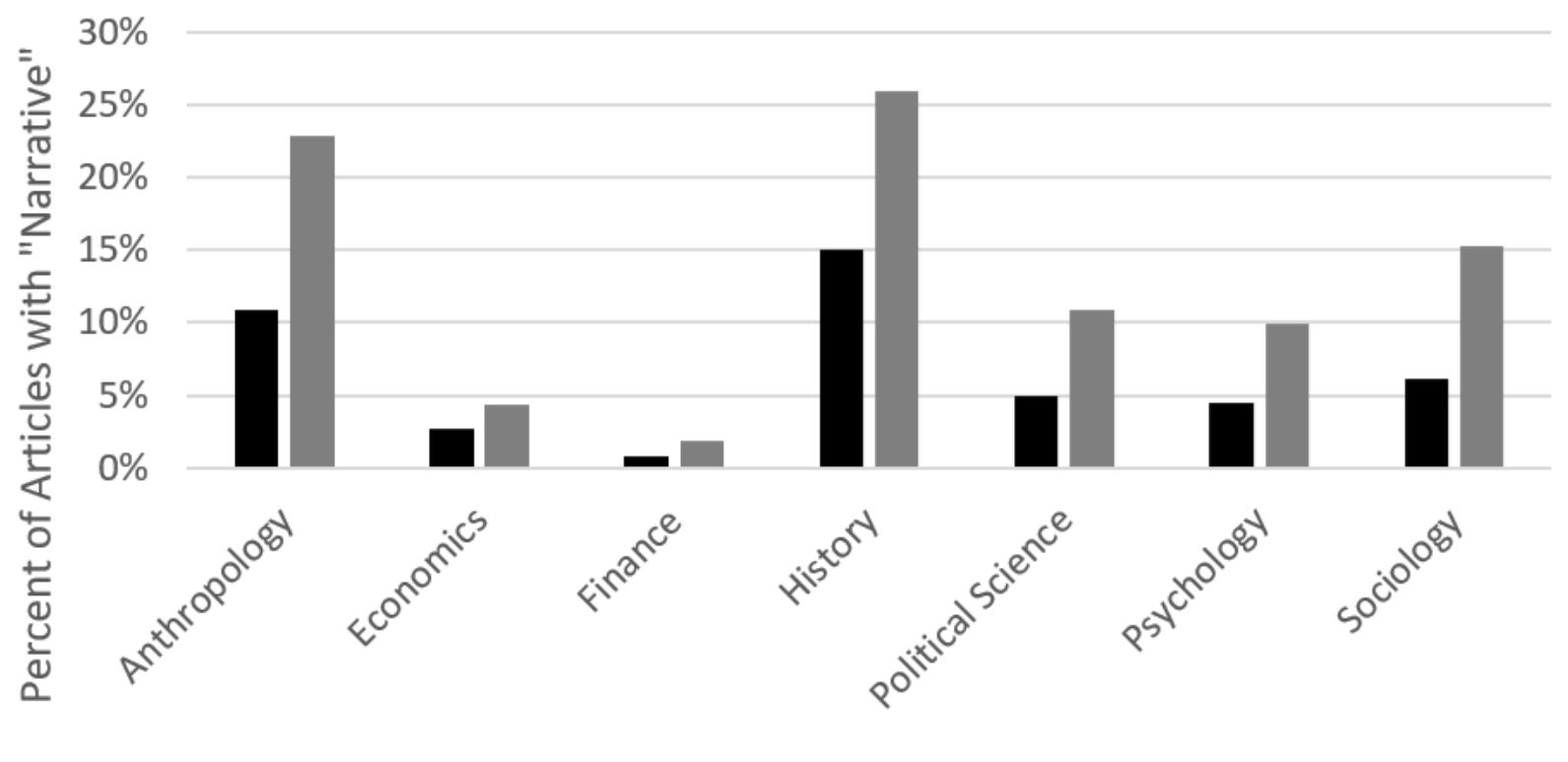

a All Dates 2010-2016

Figure 1.JSTOR counts by field of articles containing the word "narrative" as a percent of all articles in the field, entire database left and the years 2010-2016 only, right.

Some would say that the field of history has always had an appreciation for narratives. However, historians need also to be reminded sometimes that a deep understanding of history requires imputing what was on the minds of those people who made history, what their narratives were, as historian Ramsay MacMullen implored in his book, Feelings in History: Ancient and Modern (2003). He does not literally stress the concept of narratives: he has told me he would prefer a word conveying "stimulus to some emotional response, and there is no such word.” But he shows that if we try to understand people's actions, we will need to replicate in ourselves as best we can the feelings they themselves experienced, and his book describes many of the narratives that in history communicated such feelings.

In the social sciences, the last half century saw the blossoming of schools of thought that emphasized study of popular narratives, a study that has been variously named as narrative psychology (Bruner 1986); storytelling sociology (Berger and Quinney 2004); narrative approaches to religious studies 
(Ganzevoort 2013); narrative criminology (Presser and Sandberg 2015); and so on. The overriding theme is that people typically have little or nothing to say if you ask them to explain their objectives or philosophy of life, but they brighten up at the opportunity to tell personal stories, which then reveal much of their values (O'Conner 2000). For example, if one interviews in a prison, one finds that the subject tends to respond well when asked to tell stories about other criminals, and these stories tend to convey a sense not of amorality but of altered morality.

Consideration of narratives in economics brings us to an unfamiliar association with literature departments in our universities. Some literary theorists have found that certain basic structures of stories are repeated constantly, though the names and circumstances change from story to story, perhaps suggesting that the human brain practically has receptors for certain stories built in. Cawelti (1976) classifies what he calls "formula stories." Propp (1984) found 31 "functions" present in all folk stories. Tobias (1996) says that in all of fiction there are only twenty master plots: "quest, adventure, pursuit, rescue, escape, revenge, the riddle, rivalry, underdog, temptation, metamorphosis, transformation, maturation, love, forbidden love, sacrifice, discovery, wretched excess, ascension and descension.” Booker (2004) argues that there are only seven basic plots: "overcoming the monster, rags to riches, voyage and return, comedy, tragedy, and rebirth.” According to literary theorist Mary Klages (2006), structuralism in literary theory takes such efforts to list all basic stories as "overly reductive and dehumanizing." ${ }^{3}$ Although dismissing these lists of basic plots, she asserts: "structuralists believe that the mechanisms which organize units and rules into meaningful systems come from the human mind itself." ${ }^{\circledR}$ Peter Brooks (1992) says narratology should be concerned with "how narratives work on us, as readers, to create models of understanding, and why we need and want such shaping orders." ${ }^{5}$ Well-structured narratives, Brooks argues, "animate the sense-making process" and fulfill a "passion for meaning" ${ }^{\circ}$ and the study of narratives brings him to psychoanalysis.

\footnotetext{
${ }^{3}$ Klages p. 33

${ }^{4}$ Loc. Cit.

${ }^{5}$ Brooks (1992), location 74.

${ }^{6}$ Brooks, location 749.
} 


\section{Narratives as Creative, Essentially Human, Works}

Predicting the success of creative works with the public is an extremely difficult task, one that is fundamentally related to the challenge we have in predicting contagion rates of narratives. We don't precisely observe the mental and social processes that create contagion. For example, predicting the success of motion pictures before they are released is widely known to be quite difficult, (Litman 1983). Jack Valenti, former president of the Motion Picture Association of America, said:

"With all the experience, with all the creative instincts of the wisest people in our business, no one, absolutely no one can tell you what a movie is going to do in the marketplace. . Not until the film opens in a darkened theater and sparks fly up between the screen and the audience can you say this film is right."

By analogy, the reason that writers pull quotes, especially paragraph-length quotes, and display

them as I have just done is often to convey a narrative, to give the reader a historical sense of a past narrative that had impact and might again have impact on the reader if it is repeated just as it was perfectly worded. As with jokes, a narrative has to be delivered just right to be effective. Similarly, with music we want to hear again and again a performance that sounds exactly right and by the perfect performer. This is why narratives are difficult to study, and why there are limitations in textual analysis involving word counts or n-gram counts to quantify and study them.

Since around the beginning of the twentieth century, scholars from a wide array of disciplines began to think that narratives, stories that seem outwardly to be of entertainment value only, are really central to human thinking and motivation. For example, in 1938 the existentialist philosopher Jean-Paul Sartre wrote:

"A man is always a teller of tales, he lives surrounded by his stories and the stories of others, he sees everything that happens to him through them; and he tries to live his life as if he were recounting it."

'Jack Valenti, in a speech "Motion Pictures and Their Impact on Society in the Year 2001," April 25, 1978, quoted in Litman (1983) p. 159 
The tales tend to have human interest, if only suggested. By analogy, when asleep at night, narratives appear to us in the form of dreams. We do not dream of equations or geometric figures without some human element. Neuroscientists have described dreaming, which involves characters, settings, and a hierarchical event structure, as a story-telling instinct that resembles in brain activity a form of spontaneous confabulation caused by lesions of the anterior limbic system and its subcortical connections (Pace-Schott, 2013).

Anthropologists, who conduct research on the behavior of diverse tribes around the world, have observed a "universal" that people "use narrative to explain how things came to be and to tell stories" (Brown 1991). Visitors to any human society will observe people facing each other, sitting around the television - or the campfire - together, and vocalizing, and more recently, tweeting, stories, at the same time waiting to learn other's reactions, interested in feedback that will either confirm or disconfirm one's thoughts. It seems that the human mind strives to reach enduring understanding of events by forming them into a narrative that is imbedded in social interactions.

Some have suggested that it is stories that most distinguish us from animals, and even that our species be called Homo narrans (Fisher 1984) or Homo narrator (Gould 1994) or Homo narrativus (Ferrand and Weil 2001) depending on whose Latin we use. Might this be a more accurate description than Homo sapiens, i.e., wise man? It is more flattering to think of ourselves as Homo sapiens, but not necessarily more accurate.

It is important to note that narratives may not generally be acted upon reflectively, since, in the words of psychologists Schank and Abelson (1977), they may be taken as scripts. When in doubt as to how to behave in an ambiguous situation, people may think back to narratives and adopt a role as if acting in a play they have seen before. The narratives have the ability to produce social norms that partially govern our activities, including our economic actions. 
Popular narratives may have a spirit of "us versus them," a Manichean tone of revealed evil described of others in the story. Jokes are quite often at somebody else's expense - members of some other group. In extreme cases, they may be focused on events as evidence of some kind of imagined conspiracy.

Of course, it is rational for people to be alert to conspiracies, since history is filled with actual examples of them. But the human mind seems to have a built-in interest in conspiracies, a tendency to form a personal identity and loyalty to friends built around perceived plots of others. This disposition appears to be related to human patterns of reciprocity, of vengeance against presumed enemies, a tendency that has been found relevant to economic behavior (Fehr and Gächter 2000). The disposition may be amplified individually by brain damage, into a "paranoid personality disorder" that is recognized in the Diagnostic and Statistical Manual, Fifth Edition (DSM V) of the American Psychiatric Association as afflicting 2.3\% to 4.4\% of the U.S. adult population. ${ }^{8}$

There is a daunting amount in the scholarly literature about narratives, in a number of academic departments, and associated concepts of memetics, norms, social epidemics, contagion of ideas. While we may never be able to explain why some narratives "go viral" and significantly influence thinking while other narratives do not, we would be wise to add some analysis of what people are talking about if we are to search for the source of economic fluctuations. We economists should not just throw up our hands and decide to ignore this vast literature. We need to understand the narrative basis for macroeconomic fluctuations, and to think about how narrative economics ought to be more informing of policy actions now and in the future.

Narratives are major vectors of rapid change in culture, in zeitgeist, and ultimately in economic behavior. Spreading narratives, often many parallel narratives around a common theme, have been creating

\footnotetext{
${ }^{8}$ The American Psychiatric Association has discontinued in DSM V the term "paranoid schizophrenia" and other terms describing paranoid forms of other psychotic disorders. Those who were once diagnosed paranoid schizophrenic might today have two diagnoses at once: paranoid personality disorder and schizophrenia.
} 
cultural change long before the Internet revolution, when the appearance of the parallel phenomenon of computer viruses, which spread by contagion from computer to computer, popularized the virus metaphor.

Talk of the epidemic spread of narratives goes back centuries. David Hume wrote in 1742:

“... when any causes beget a particular inclination or passion, at a certain time and among a certain people, though many individuals may escape the contagion, and be ruled by passions peculiar to themselves; yet the multitude will certainly be seized by the common affection, and be governed by it in all their actions."

Charles McKay drew attention to the contagious spread of "extraordinary popular delusions"

(1841). Gustave Le Bon said in his book Psychologie des foules (The Crowd): "Ideas, sentiments, emotions, and beliefs possess in crowds a contagious power as intense as that of microbes” (Le Bon 1895).

Related terms were collective consciousness (Durkheim 1897), collective memory (Halbwachs 1920s), memes (Dawkins 1976). Contagion is also related to issues of identity, since an important part of most narratives describing past events involving people is that one must imagine oneself as another person, and thus momentarily at least feel a shared identity with someone else (Akerlof and Kranton 2011).

\section{Dimensions of Narratives Normal and Abnormal}

The psychologist Jerome Bruner, who has stressed the importance of narratives, wrote that we should not assume that human actions are ever driven in response to purely objective facts:

"I do not believe that facts ever quite stare anybody in the face. From a psychologist's point of view, that is not how facts behave, as we well know from our studies of perception, memory, and thinking. Our factual worlds are more like cabinetry carefully carpentered than like a virgin forest inadvertently stumbled upon."

Narratives are human constructs that are mixtures of fact and emotion and human interest and other extraneous detail that form an impression on the human mind.

${ }^{9}$ Hume (1788) p. 103.

${ }^{10}$ Bruner (1998) p. 18. 
Psychiatrists and psychologists recognize that mental illness is often an extreme form of normal behavior, or a narrow disruption of normal human mental faculties. So we can learn about the complexities of normal human narrative brain processing by looking at dysnarrativia, abnormal narrative phenomena. Neuroscientists Young and Saver (2001) listed some of its varied forms: arrested narration, undernarration, denarration, confabulation.

Schizophrenia may be regarded as another brain anomaly related to narrative problems (Gaser et al. 2004). Schizophrenia has aspects of being a disorder of narrative, as it often involves the hearing of imaginary voices delivering a fantastic, and disordered, narrative (Saavedra et al. 2009). Hearing voices as a symptom of schizophrenia is correlated with volume deficits in specific brain areas (Gaser et al. 2004). The narrative disruption found in autism spectrum disorder also is related to brain anomalies (Losh and Gordon 2014), (Pierce et al. 2001).

Narrative psychology is also related to the psychologists' concept of framing (Kahneman and Tversky 2000), Thaler (2015, 2016). If we can create an amusing story that will get retold, it can establish a point of view, a reference point, which will have influence on decisions. It is also related to the Kahneman and Tversky representativeness heuristic (1973), whereby people form their expectations based on similarity of circumstance to some idealized story or model, and tend to neglect base-rate probabilities.

Psychologists have noted an affect heuristic, whereby people who are experiencing strong emotions, such as fear, tend to extend their feelings to unrelated happenings (Slovic et al. 2007). Sometimes people note strong emotions or fears about possibilities that they know logically are not real, suggesting that the brain has multiple systems for assessing risk, and the "risk as feelings" hypothesis that some primitive brain system more connected to palpable emotions has its own heuristic for assessing risk (Lowenstein et al. 2001.)

In joint work with William Goetzmann and Dasol Kim (2016), using data from a questionnaire survey I have been conducting with institutional investors and high-income Americans since 1989, we found 
that these people generally have exaggerated assessments of the risk of a stock market crash, and that these assessments are influenced by the news stories, especially front page stories, that they read. One intriguing finding was that an event such as an earthquake could influence estimations of the likelihood of a stock market crash. The respondents in our survey gave statistically significantly higher probabilities to a stock market crash if there had been an earthquake within 30 miles of their zip code within 30 days, triggering the affect heuristic. It seems reasonable to hypothesize that local earthquakes start local narratives with negative emotional valence. Analogous evidence has been found of seemingly irrelevant events with narrative potential having effects on economic or political outcomes: the effect of World Cup outcomes on economic confidence (Dohmen et al. 2006,) and of background music in advertisements on viewers (Boltz et al. 1991).

The news media, for which the survival of any one organization is never assured in a competitive news marketplace, must become adept at managing the news to make narratives work in their favor. Moreover, news media embellish the emphasized news with human interest stories. Given the large and often dramatic degree of news media coverage of disasters - natural and man-made - and of crimes and human interest stories, it seems clear that news media believe that covering such events will result in increased sales and attention for their news products. However, little attention has been given to the impact of such news stories on other stories in the same publication.

\section{Epidemic Models}

The Kermack-McKendrick (1927) mathematical theory of disease epidemics marked a revolution in medical thinking because it gave a realistic framework for understanding the all-important dynamics of infectious diseases. Their simplest model divided the population into three compartments: susceptibles, infectives, and recovereds, hence it is called an SIR Model or compartmental model. $S$ is the number of susceptibles, people who have not had the disease and are vulnerable. $I$ is the number of infectives, people who have the disease and are actively spreading it. $R$ is the number of recovereds, who have had the disease 
and gotten over it and are no longer capable of catching the disease again or spreading it. The total population $N=S+I+R$ is assumed constant.

The key idea of the Kermack-McKendrick mathematical theory of disease epidemics was that in a thoroughly mixing population the rate of increase of infectives in a disease epidemic is equal to a constant contagion rate $c>0$ times the product of the number of susceptibles $S$ and the number of infectives $I$ minus a constant recovery rate $r>0$ times the number of infectives. Each time a susceptible meets an infective there is a chance of infection. The number of such meetings per unit of time depends on the number of susceptible-infective pairs in the population. The recovery from the disease is assumed for simplicity to occur in an exponential decay fashion, instead of the more usual notion of a relatively fixed timetable for the course of the disease. The three-equation Kermack-McKendrick SIR model is:

$$
\begin{gathered}
\frac{d S}{d t}=-c S I \\
\frac{d I}{d t}=c S I-r I \\
\frac{d R}{d t}=r I
\end{gathered}
$$

The same SIR model can of course be used to describe the word-of-mouth transmission of an idea. Here, the contagion rate is the fraction of the time that an encounter between an infective, a person interested in and accepting of a story, effectively convinces the susceptible enough of the story to spread it further. Many encounters may be needed before a particular person is infected. The removal rate might be described as the rate of forgetting, of simple decay of memories, but there is also cue-dependent forgetting. This removal also occurs as the repertory of other current stories evolves away from this story, so that there are declining cues for the memory; this story seems less connected, less apt, or even superficially contrary to current theories and prejudices. It might be plausible to suppose, as the model does, that contagion rates and removal rates are both constant through time, if they are intrinsic to the narrative. Inaccurate retellings 
of the narrative that leave out its essential interest value, because of transmission error, just don't survive, the parameter $c$ refers to successful spread of the core interest value of a story.

Even though direct face-to-face communications of ideas is less important in modern times because of the communications media, it still remains a workable model. The core model may apply no matter how people may connect with each other.

This model implies that from a small number of initial infectives, the number infected and contagious itself follows a bell-shaped curve, rising at first, then falling. A mutation in an old much-reduced disease may produce a single individual who is infective, and then there will be a lag, possible a long lag if $c$ is small, before the disease has infected enough people to be noticed in public. The epidemic will then rise to a peak, and then fall and come to an end without any change in the infection or removal rates, and before everyone is infected.

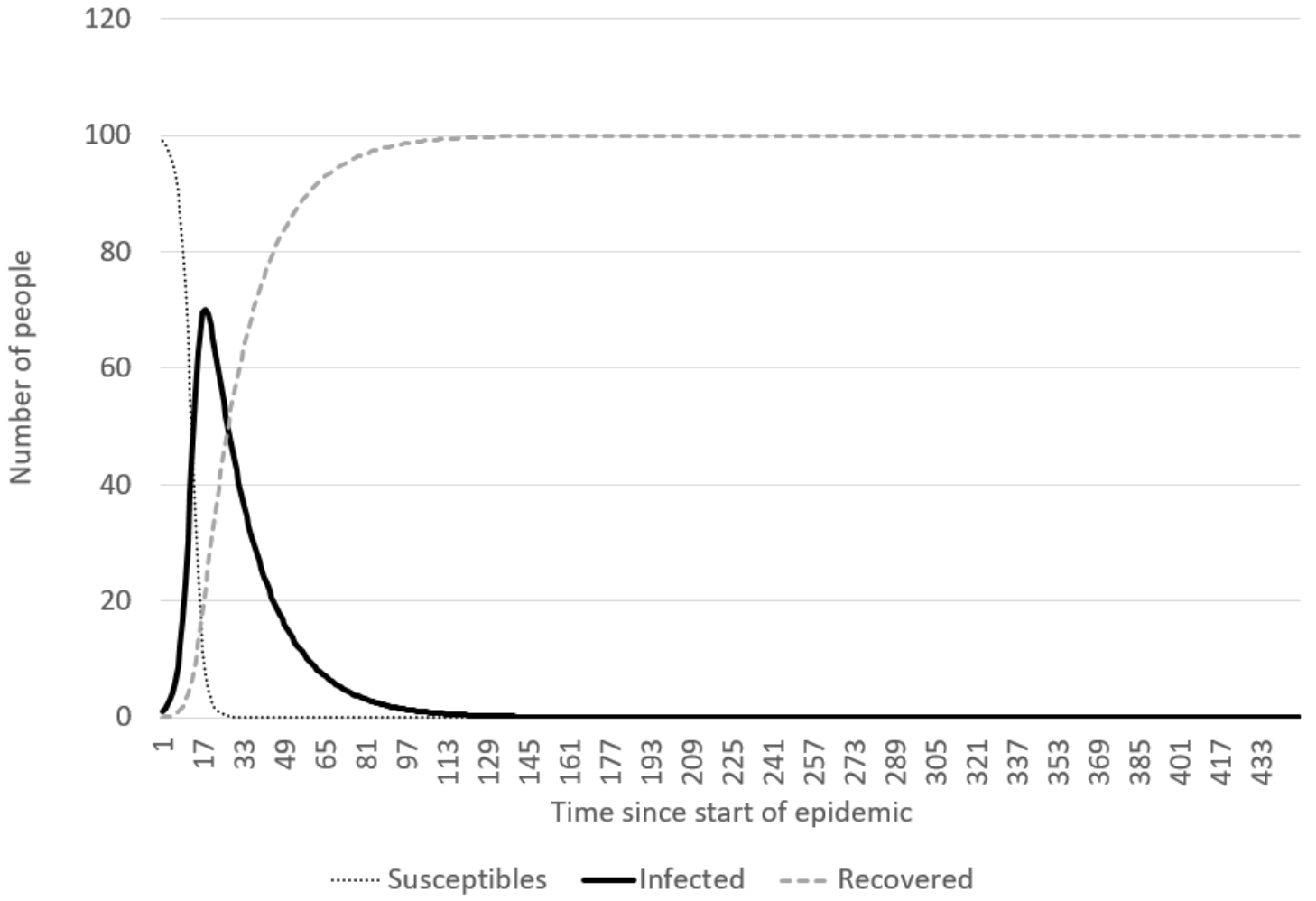

Figure 2. Solution to Kermack-McKendrick SIR model for $N=100, I_{0}=1 \quad c^{=} .005, I^{=} .05$. 
Figure 2 shows an example, implied by the above three equations, with $N=100$ people, very small transmission of infection per unit of time on any one exposure, $I_{0}=1 \quad c^{=} .005, r^{=} .05$. In this case, almost $100 \%$ of the population eventually gets infected. During an actual epidemic, public attention tends to focus on the number of infectives, seen here as a bell-shaped curve skewed to the right.

Not everyone will ever catch the disease as some completely escape for lack of effective encounter with an infective, and gradually it gets safer and safer for them because the infectives are becoming more and more reduced in number as they get over the disease and are immune to it, so there are not enough new encounters to generate sufficient new infectives to keep the disease on the growth path. Eventually, the infectives almost disappear, and the population consists almost entirely of susceptibles and recovereds.

What creates a big disease that ultimately reaches a lot of people (the total ever infected and recovered as measured by $\left.R_{\infty}\right)$ ? It is a function of the ratio $c / r$ of the two parameters. As time goes to infinity, the number of people who have ever had the disease goes to a limit $\boldsymbol{R}_{\infty}$ (called the size of the epidemic) strictly less than $N$. It follows directly from the first and third equations that $d S / d R=-(c / r) S$ and the initial condition $\mathrm{I}_{0}$ that $S=\left(N-I_{0}\right) e^{-\left(\frac{c}{r}\right) R}$ and since $I_{\infty}=0, N=S \infty+R \infty$ we have:

$$
\frac{c}{r}=R_{\infty}^{-1} \log \frac{N-I_{0}}{N-R_{\infty}}
$$

If we could choose $c$ and $r$, we could make the size of the epidemic $R_{\infty}$ anything we want between $I_{0}$ and $N$. Higher $c / r$ corresponds to higher size of epidemic $R_{\infty}$, regardless of the level of $c$ or of $r$, while higher $c$ itself, holding $c / r$ constant, yields a faster epidemic. If we define "going viral" by $R_{\infty}>N / 2$, then we see this happening in this example when $c / r>.014$.

If we multiply both parameters, $c$ and $r$, by any constant $a$, then the same equations are satisfied by $S(a t), I(a t), R(a t)$. This means, depending on the two parameters $c$ and $r$, that there can be both fast and slow epidemics that look identical if the plot is rescaled. If we also vary the ratio $\mathrm{c} / \mathrm{r}$, we can have epidemics that play out over days and reach $95 \%$ of the population, or epidemics that play out over decades and reach 
$95 \%$ of the population, or epidemics that play out over days and reach only $5 \%$ of the population, or epidemics that play out over decades and reach $5 \%$ of the population. But in each case, we can have humpshaped patterns of infectives that on rescaling look something like that in Figure 2.

The Kermack-McKendrick SIR model (1927) has formed a starting point for mathematical models of epidemics that have, over 90 years since, produced a huge literature. The basic compartmental model, the SIR model, has been modified to allow for gradual loss of immunity, so that recovereds are gradually transformed into susceptibles again (the SIRS model). This is the same as the SIR model above except that a term $+s R$ is added to the right hand side of the first equation and $-s \boldsymbol{R}$ to the right hand side of the third equation, where $s>0$ is a re-susceptibility rate. In this model the infectives' path may, depending on parameters, look similar to that in Figure 2 but approaching a nonzero horizontal asymptote as time increases: the infectives never effectively disappear. The SIR model can also be modified so that an encounter between a susceptible and an infected leads to an increase in exposed $E$, a fourth compartment, who become infective later (the SEIR model). The model has also been modified to incorporate partial immunity after cure, birth of new susceptibles, the presence of superspreaders with very high contagiousness, geographical patterns of spread, etc.

\section{Applications of the Kermack-McKendrick to Social Epidemics}

In applying the compartmental model to social epidemics, to epidemics of ideas, certain changes seem natural. One thought is that the contagion rate should decline with time, as the idea becomes gradually less exciting. Another way of modeling approximately the same notion is due to Daley and Kendall $(1964,1965)$ who said that the Kermack-McKendrick model could be altered to represent that infectious people might tend to become uninfectious after they meet another infectious person or a recovered person, because they then think that many people now know the story, making it no longer new and exciting, and thus they choose not to spread the epidemic further. 
Bartholomew (1982) argued that when variations of the Kermack-McKendrick model are applied to the spread of ideas, we should not assume that ceasing to infect others and forgetting are the same thing. Human behavior might be influenced by an old idea not talked about much but still remembered. This has been called "behavioral residue" (Berger, 2013).

There is now a substantial economics literature on network models, see the recent Handbook on Network Economics (Bramoullé 2016), though there appears to be little in the way of such behavioral models (the word narrative does not appear even once in the Handbook). Some of these modified SIR Models involve complex patterns of outcomes, and sometimes cycles. Geographic models of spread are increasingly complicated by worldwide social media connections (Bailey et al. 2016).

Some SIR models (surveyed in Lamberson 2016) dispense with replacing the idea of random mixing and choose instead a network structure. There may be strategic decisions whether or not to allow oneself to be infected, and the fraction of the population infected may enter into the decision (Jackson and Yariv 2005). There are variations of models that describe individuals as adopting a practice not merely through random infection but through rational calculations of the information transmitted through their encounters with others (Banerjee 1992; Bikhchandani, Hirshleifer and Welch. 1992).

Currently, there is not any one single model for social epidemics, instead there is a tool bag of models for understanding epidemics depending on their circumstances. But we can still refer to the original Kermack-McKendrick SIR model as a metaphor for the class of dynamic models that rely on contagion and recovery. These other models typically still take analogues of $c$ and $r$ as fundamental parameters, still have the property that a slight tweak of $c$ upwards or $r$ downwards may set in motion a chain of events that sets off an epidemic with a lag, so that on the date the epidemic is first publicly noticed, the causes are now in fairly distant history and hard to discern.

Even though direct face-to-face communication of ideas is less important in modern times, because of the communications media, the Kermack-McKendrick model still remains an important model for 
economics. The core model may apply no matter what way people may connect with each other. There is a concern that modern communications media (the press, the Internet, etc.) make the SIR model less accurate in describing social epidemics. But the change may instead be roughly within the framework of the model, with higher contagion rates for narratives due to the social media automatically directing narratives to people with likely interest in them, regardless of their geography. Moreover, marketing literature finds that direct word-of-mouth communications still beat other forms in persuasiveness (Herr et al. 1991), and the marketing profession has responded by promoting word-of-mouth seeding strategies and television ads that feature actors portraying people with whom the common person can identify and simulating direct interpersonal word of mouth. In considering whether the Internet and social media and the SIR model, Zhao et al. (2013) argue for a modified SIR model where analogues to the parameters $c$ and $r$ are both increased by the new media.

Bauckhage (2011) showed evidence that the SIRS variant of the Kermack-McKendrick compartmental model fits time series data reasonably well on Internet memes from Google Insights (now Google Trends.) He looked at silly recent Internet viruses like the "O RLY?” (Oh, really?) meme that displayed nothing more than a picture of a cute owl with what would appear to be a puzzled facial expression. Because the memes are largely nonsensical, we might expect them to follow a course independent of other ideas and thus to fit the SIRS model well, as he found. Roughly the same humpshaped pattern of infectives was found again and again.

Michele et al. (2011) showed evidence that mentions of famous people in books tends to follow a hump-shaped pattern through time, a slow epidemic, something like those observed by Bauckhage, but over decades, rather than months or years. Some examples from economists possibly illustrate a compartmental model slow epidemic, a hump shaped pattern that plays out over centuries. Adam Smith (1723-1790) has a Google Ngrams plot that did not peak until the 1880s, and has since been declining slowly for over a century. Karl Marx (1818-1883) has a Google Ngrams plot that did not peak until the 1970s. 
Taking the Kermack-McKendrick model as an illustration or metaphor, it would appear that this learning theory might imply that the total impact of an idea is measured by its $R_{\infty}$ long after the idea has ceased to be infectious. The long-run impact of an idea then is not testimony to its correctness, but rather to the $c / r$ in the initial epidemic that popularized it.

In applying the SIR model to social epidemics, we need also consider that narratives affect the contagion rates of other narratives that are seen to be on the same topic or that further inform. One new narrative may remind of another that has been lying fairly dormant. A wave of similar narrative epidemics can appear.

One must also consider that stories tend to be strategic, fine-tuned by politicians, advertisers, or other interested parties (Akerlof and Shiller, 2015). People with an aptitude for storytelling see great fortune in monkeying with stories in an effort to have them go viral. Falk and Tirole (2016) call them "narrative entrepreneurs." Glaeser (2005) refers to the "supply of stories," exemplified by hate-creating stories crafted, produced, fashioned for political advantage. Gino et al. (2016) describe concoctors of excuses "motivated Bayesians" meaning that these people start to believe the fake news that they generated for self-advantage.

Much of the purposeful generation of new stories is for individual profit, but some of it is done in a patriotic attempt to support confidence and good values. The process of perfecting stories is one of trial and error, and responsiveness to the kinds of things that go viral. A successful story entrepreneur may have a lifetime of failed attempts and perhaps only one or a few breakthroughs. The rare breakthroughs make the entire enterprise worthwhile.

\section{Narrative Epidemics of Economic Theories}

Let us consider as an example the narrative epidemic associated with the Laffer Curve, a diagram created by economist Arthur Laffer in the theory of public finance. Let's curve the curve, look at KermackMcKendrick curves for the narrative of the Laffer Curve. Looking at the Laffer Curve is an arbitrary choice among a vast number of narratives, but one that can be searched on databases easily since the name "Laffer 
Curve” appears to connect well to a single narrative with clear economic impact. This narrative exploded into public attention in 1978 focusing on a 1974 event involving the U.S. economist Art Laffer. In Figure 3, a plot of the frequency of references to the Laffer Curve by year, from ProQuest News \& Newspapers and by Google Ngrams, somewhat resembles the infectives plot of the Kermack-McKendrick model in Figure 2.

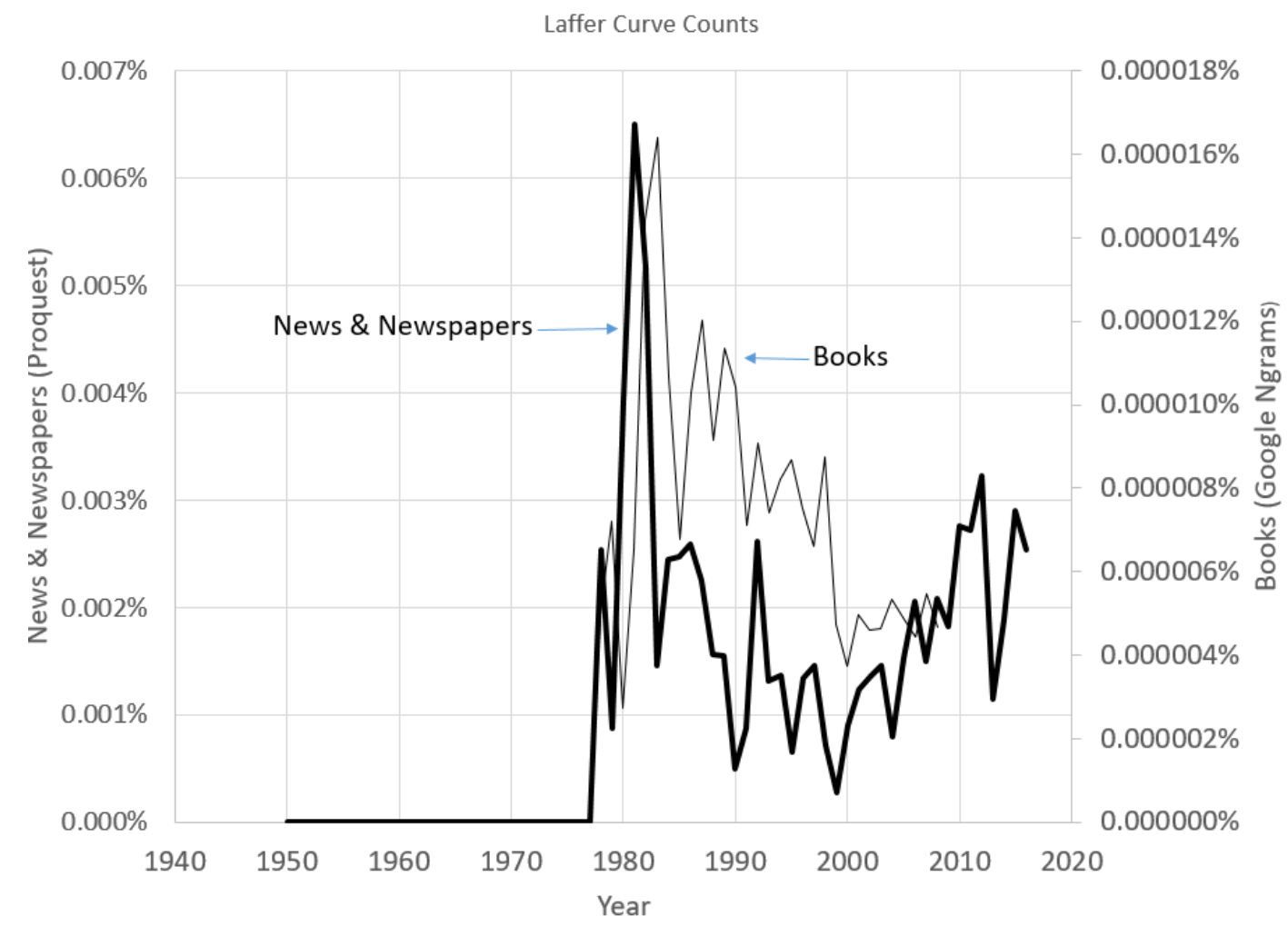

Figure 3. Frequency of appearance of "Laffer Curve" by year. For news and newspapers (1950-2016, from ProQuest) it is the number of articles with this phrase as a percent of all articles that year. For books (19502008, from Google Ngrams) it is the number of occurrences of "Laffer Curve" divided by the total number of words in the database for that year, in percent.

For both, the curves are choppy relative to the model, due to some publication noise, but show some of the hump shape. For news and newspapers, the frequency of use of the term "Laffer Curve" initially rises strongly, from 1977 to 1978, and then rises rapidly for three more years, peaking in 1981 . Then it falls and continues to fall for many years, as in the model Figure 2, though it shows something of an 
upturn again after 2000. For books, the curve rises more slowly, for five of six consecutive years, from 1978 to 1983, before entering a long period of slow decline, as in the model Figure 2.

The Laffer Curve owes much of its contagion to the fact that it was seen as justifying major tax cuts. The Laffer Curve's contagion related to fundamental political changes associated with Ronald Reagan's election as U.S. president in 1980 with his commitment to cutting taxes (and with Margaret Thatcher, but not the socialist François Mitterrand elected around that time).

The Laffer Curve is an inverted $\mathrm{U}$ curve relating tax revenue to tax rates, a theory that was used to justify cutting taxes on high-income people since high taxes incentivize them to produce less. The notion that taxes might reduce the incentive to earn income and create jobs was hardly new: the idea was expressed as long ago as Adam Smith in the eighteenth century. ${ }^{11}$ Andrew Mellon, U.S. Treasury Secretary, 1921-32, was famous for his “trickle down” economics, and, along with U.S. President Calvin Coolidge, 1923-9, successfully argued for reduction of income taxes that had remained high for a while after World War I. But then the Mellon name began to fade (outside of Carnegie-Mellon University), and the theory lost persuasive narrative.

The story of the Laffer Curve did not go viral in 1974, the reputed date when Laffer first introduced it. Its contagion is explained by a literary innovation that was first published in a 1978 article in

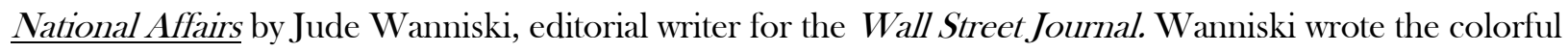
story about Laffer sharing a steak dinner at the Two Continents in Washington D.C. in 1974 with top White House powers Dick Cheney ${ }^{12}$ and Donald Rumsfeld ${ }^{13}$, as well as Wanniski. Laffer drew his curve on a napkin at the restaurant table. When news about the "curve drawn on a napkin" came out, with Wanniski's help, this story surprisingly went viral, so much so that it is now commemorated. A napkin with

\footnotetext{
"Adam Smith Wealth of Nations Vol. II (1869) [A tax] may obstruct the industry of the people, and discourage them from applying to certain branches of business which might give maintenance and employment to great multitudes.” P. 416.

${ }^{12}$ Cheney was as of 1978 soon to be White House Chief of Staff, later Secretary of Defense and Vice President of the United States.

${ }^{13}$ Rumsfeld was as of 1978 recently secretary of Defense.
} 
the Laffer Curve can be seen at the National Museum of American History, and a reenactment video of the restaurant-napkin event depicting Laffer drawing his curve on a napkin is available on Bloomberg.

Why did this story go viral? It is always hard to explain these things. Laffer himself said after the Wanniski story exploded that he could not even remember the event, which had taken place four years earlier. ${ }^{14}$ But Wanniski was a journalist who sensed that he had the right elements of a good story. The key idea as Wanniski presented it, is indeed punchy: At a zero-percent tax rate, the government collects no revenue. At a $100 \%$ tax rate the government would also collect no revenue, because people will not work if all of the income is taken. Between the two extremes, the curve, relating tax revenue to tax rate, must have an inverted U shape. Now, as Wanniski pointed out with fanfare in the opening line of his 1978 article, this means that for any feasible tax revenue except one at the very top of the Laffer Curve, there are two tax rates that will generate this $\mathrm{U}$ shape, one at the left with a high-income level and low tax rates, the other at the right with a low-income level and high tax rates.

Here is a notion of economic efficiency easy enough for anyone to understand. Wanniski suggested, without any data, that we are on the inefficient side of the Laffer Curve. Laffer's genius was in narratives, not data collection. The drawing of the Laffer Curve seems to suggest that cutting taxes would produce a huge windfall in national income. To most quantitatively-inclined people unfamiliar with economics, this explanation of economic inefficiency was a striking concept, contagious enough to go viral, even though economists protested that we are not actually on the inefficient declining side of the Laffer Curve (Mirowski 1982). It is apparently impossible to capture why it is doubtful that we are on the inefficient side of the Laffer Curve in so punchy a manner that it has the ability to stifle the epidemic. Years later Laffer did refer broadly to the apparent effects of historic tax cuts (Laffer 2004); but in 1978 the

\footnotetext{
"Paul Blustein, 1981. "New Economics: Supply-Side Theories Became Federal Policy with Unusual Speed." The Wall Street Journal. October 8, 1981, p. 1.
} 
narrative dominated. To tell the story really well one must set the scene at the fancy restaurant, with the powerful Washington people and the napkin.

Another fad, associated with multiple narratives, appeared around the same time as the Laffer Curve: “Rubik’s Cube.” Rubik's Cube was bigger than Laffer Curve on ProQuest News and Newspapers, but smaller than Laffer Curve on Google Ngrams. They both show similar hump-shaped paths through time.

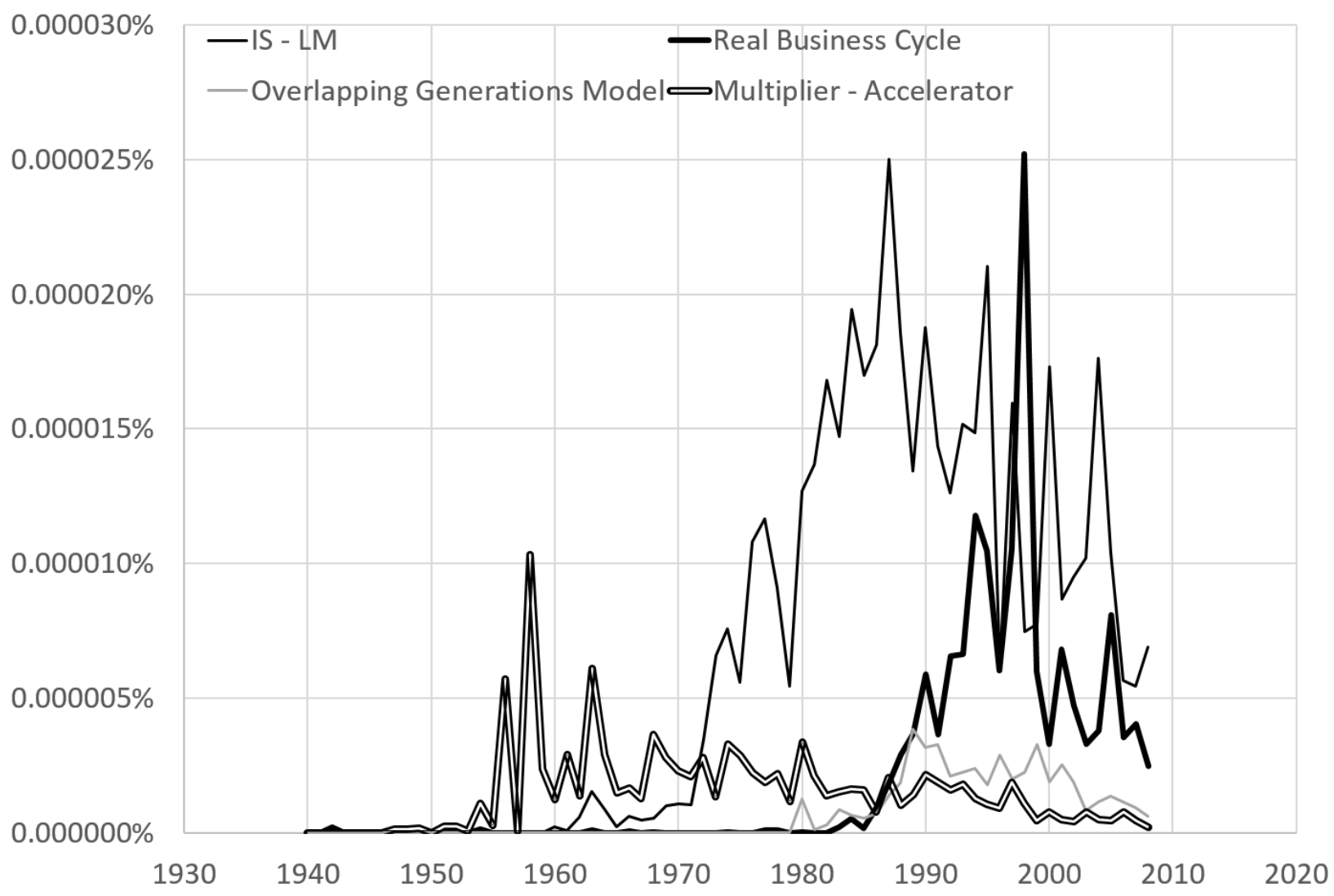

Figure 4. Google Ngrams counts for four economic theories: IS-LM (Hicks 1937), Multiplier-Accelerator (Samuelson 1939), Overlapping Generations Model (Samuelson 1958) and Real Business Cycle model (Kydland and Prescott, 1982).

The Laffer Curve epidemic was followed during the Reagan presidency (1981-89) by a reduction in the top U.S. federal income tax bracket from $70 \%$ to $28 \%$. The top-bracket U.S. corporate profits tax rate 
was cut from $46 \%$ to $34 \%$ during the Reagan administration. The top U.S. capital gains tax rate was reduced from $28 \%$ to $20 \%$ in 1981 (though raised back to $28 \%$ again in 1987 during the Reagan presidency). If the Laffer Curve epidemic had even a minor effect on these changes, it must have had tremendous impact on measures of output and prices.

Figure 4 shows Google Ngrams results for several other examples of economic theories, though less appropriate for our purposes because they are not just narratives, they are more substantively original than the Laffer Curve. Still, even important original theories have associated narratives and might have SIR dynamics. The IS-LM model (Hicks 1937); the multiplier-accelerator model (Samuelson 1939); the overlapping generations model (Samuelson 1958); and the real business cycle model (Kydland and Prescott, 1982); all show hump-shaped patterns akin to those that can be produced by the Kermack-McKendrick model, as seen in Figure 2. In three of the cases, the epidemic first became visible more than a decade after the model was introduced, a phenomenon that is also explainable within the Kermack-McKendrick framework, where epidemics may go unobserved for a while after they have just started from very small beginnings.

\section{Feedback Variations: Multipliers and Bubbles}

To think of the events surrounding the explosion of the Laffer Curve as a social epidemic is to think about feedback. The original Kahn-Keynes multiplier model in macroeconomics (Kahn 1931, Keynes 1936) with its famous "multiple rounds of expenditure" might be described as a sort of epidemic model but with the contagion rate $c$ replaced by MPC, the Marginal Propensity to Consume, and with a zero removal rate $r$. It was an appealing feedback model, on paper. Any stimulus to the economy, call it $I_{0}$ to show parallel with our epidemic model, increases someone's income. This individual, who then spends MPC of that income, generating income for yet another who spends MPC of that income, and so on, such that national income rises gradually, and eventually the result is an increase of national income of $I_{0} /(1-\mathrm{MPC})$. 
In practice, however, the purely Keynesian form of contagion is limited. Some estimates of the multiplier are very low, implying that this kind of contagion may not be as important as it seemed at first. The "permanent income hypothesis" suggests that Keynesian contagion may be very low if people do not believe that the spurt in income will be permanent. Some research supports low multipliers, for example Matthew Shapiro (2016) reports on research of his own and of co-authors, based on survey questions conducted by the University of Michigan's Survey of Consumers, of the impact of fiscal stimulus policies. The presented counterfactuals (what would you have done differently if you did not receive the tax rebate check) and found that, at least at the time of their survey, the marginal propensity to consume may have been quite low, between one quarter and one third, suggesting a multiplier little different from one.

A different special kind of epidemic model describes speculative bubbles. Speculative asset prices themselves would not generally be well modeled directly in terms of this model since the model yields smooth-through-time paths. Most speculative asset prices are nearly random walks on a day-to-day basis. The reason is obvious: if it were possible for smart money to predict the day-to-day price changes even reasonably well, they could become rich very fast, and they would take over the market. There are both smart money and noise traders in the market, the former attempting to predict the latter. ${ }^{15}$ There is a large literature on value investing that confirms that there has been a long-term return to doing it. ${ }^{16}$

In a bubble, the contagion is altered by the public attention to price increases: rapid price increases boost the contagion rate of popular stories justifying that increase, heightening demand and more price increases. In a stock market bubble, these might be stories of the companies with glamorous new technology and of the people who created the technology. In a housing bubble, these might be stories of

\footnotetext{
${ }^{15}$ There is a substantial literature on "noise traders" in finance, see for example LeRoy and Porter (1981), Shiller (1981, 1984), Summers (1986), De Long, Shleifer Summers and Waldman (1990), Shleifer and Vishny (1997).

${ }^{16}$ See for example Fama and French (1993).
} 
clever people making a fortune flipping houses. There can also be price-to-GDP-to-price feedback, if speculative price increases stimulate purchases and hence more increases, price-to-corporate profits-to-price feedback, and price-to-regulatory laxity-to-price feedback, all mediated by changing narratives (Shiller 1984, 2000, 2015).

The impact of the epidemic on the asset return would depend on the speed of the epidemic relative to the discount rate. If the speed is very low, there would be very little impact on short-term returns. Then the asset price changes would find little short-term serial correlation through time, and would be approximately a random walk over short time periods.

Narratives during the sharpest (though not the worst) U.S. contraction ever: 1920 to 1921. In looking for the narrative basis of economic recessions, which might be hard to see since narratives are not easy to measure, it would appear that we would have the most luck looking at really big ones: 1920-21 was the sharpest U.S. recession since modern statistics are available. The U.S. Consumer Price Index switched suddenly from inflation to deflation: between June of 1920 and June of 1921, during the Depression, it fell $16 \%$, the sharpest one-year deflation ever experienced in the United States. The Index of Wholesale Prices fell much more: $45 \%$ over the same time interval, its sharpest decline ever. ${ }^{17}$ The cyclically adjusted price earnings ratio (real S\&P Composite Index divided by ten-year average of real earnings, Campbell and Shiller 1988) fell to 4.78 by December 1920, by far the lowest ratio in the entire history of the U.S. stock market since 1871 . In contrast, note that the ratio is currently around 28. The conventional price-earnings ratio with 12-month trailing earnings was also extremely low, at 8.51. This was the recession that, because of its severity, influenced the fledgling National Bureau of Economic Research (NBER) towards a research program emphasizing the study and dating of business cycles.

\footnotetext{
${ }^{17}$ St. Louis Fed Fred II M04049USM052NNBR, source: National Bureau of Economic Research.
} 
Surprisingly, the online NBER Working Paper Series, almost a hundred years later, when searched, has virtually nothing to say about what caused this spectacular depression. Why, after all, did it happen?

Milton Friedman and Anna J. Schwartz, in their Monetary History of the United States, have given the most influential account. According to them, the 1920-21 contraction has a single identifiable cause: an error made by the fledgling Federal Reserve to raise the discount rate to trim out-of-bounds inflation in 1919 caused by their carelessly over-expansionary policy right after World War I, leading to a necessity to take strong measures against inflation in 1920. Benjamin Strong, the president of the New York Fed, was on a long cruise starting December 1919, and was unable to prevent Federal Reserve Banks (which did not coordinate their policies with each other so much back then) from raising the discount rate as much as a full percentage point in one shot in January 1920.

The Fed was new then, having opened its doors only in 1914, and so it is not surprising that they could have made mistakes and implemented overly strong swings in policy. But let us not jump to conclusions about the Fed having caused the depression. Other remarkable things were going on too. If we are going to single out significant events for study, we should keep in mind that important events are usually the result of the confluence of many factors, and often changing narratives are at work in those factors.

There was a background then of horrible recent events: World War I, which ended only 14 months before the start of the depression, an influenza epidemic even more deadly than the war that started during the war and was not quite over, and a series of postwar race riots in the United States. But how did these events translate into current narratives in 1920 ?

I am reminded of a book about the 1920s, Only Yesterday: An Informal History of the 1920s, written by a popular writer, Frederick Lewis Allen, published in 1931, which commented on the early stages 
of the Great Depression in its Afterword. ${ }^{18}$ His history emphasizes all the little silly fads and diversions that occupied people's attentions, and might be considered a history of silliness, except that some of the events portrayed were ominous or deadly.

The 1920-21 recession also began with the early stages of widespread public fear of Communism. A computer search of news and newspapers on ProQuest shows relatively little use of the term Communist before 1919. Certainly, Karl Marx and Friedrich Engels wrote their Communist Manifesto long before, in 1848, and newspapers did write about them, though much less frequently. Most people could not be bothered to learn some abstract Communist theory if there had never been a real Communist revolution. Marx and Engels often were seen as minor eccentrics. But after 1918, there was a sudden jump in focus on Communism.

Allen (1931) writes of the Big Red Scare period in America:

"They [Americans] were listening to ugly rumors of a huge radical conspiracy against the government and institutions of the United States. They had their ears cocked for the detonation of bombs and the tramp of Bolshevist armies. They seriously thought-at least millions of them did, millions of otherwise reasonable citizens-that a Red revolution might begin in the United States the next month or next week." ${ }^{19}$

Notably, there is a very dramatic story of the sudden advance of communism after World War I, and its brutality: the murder of Czar Nicholas II and his entire family by Communists on June 17, 1918. It is a particularly repellant story of an internationally recognized family (readers all over the world had seen them in photogravures in newspapers and postcards, much as we routinely see the British Royalty today), who were asked to dress up, then seated and executed at the surprise appearance of a firing squad. The announcement of the Czar's death appeared in newspapers by June 28, 1918, but not all the gory details

\footnotetext{
${ }^{18}$ Here, I am rereading the same copy of the book that was assigned to me as an undergraduate at the University of Michigan over 50 years ago in Prof. Shaw Livermore's History 332 course "Individualism vs. Collectivism” when I was 19 years old. I still have the same copy of the book, for which I then paid 85 cents new, and I still have my handwritten lecture notes from that class. Lest you think, those of you who teach, that your lectures are soon forgotten, note that I have been thinking of his lectures and book assignments ever since. The removal rate is sometimes very low. ${ }^{19}$ Allen, 1931, p. 38.
} 
were made available to the public until the Report of the Inquiry at Ekaterinburg in September 1920, in the middle of the Depression. Then this story - certainly a contagious story, and one that would attract readers was reported in excruciating detail by newspapers around the world. The story lives on today; it persists in diminished form as a long, slow epidemic of the kind with low contagion rate but equally low removal rate.

There was also an oil price shock, which generated its own narratives. U.S. oil prices rose over $50 \%$ from mid-1919 to the end of 1920, in the middle of the Depression. Because consumer prices were falling then, the real price increase was even greater, and by the end of 1920, real oil prices were at the highest level in the20th century before 1979.

Some newspapers did offer a straightforward interpretation of the high oil prices: temporary supply disruptions in Russia and Mexico because of unrest there. But, another explanation had a higher contagion rate. High oil prices were then attributed to strong demand at a time when automobiles and other energyintensive devices were proliferating despite the Depression. An article by W. W. Woods in the Los Angeles Times in September 1920 said: "In the last two years the growing appetite of the internal combustion engine for gasoline has been more than six times what it was in 1901." He concluded that the nation's oil supply would be exhausted in eighteen years. Moreover, coal prices were high in late 1920, and retail stores of coal for home furnaces were reportedly exhausted as winter approached. Clayton (2015) documents the history of this narrative, from Teddy Roosevelt's 1908 White House conference on exhaustion of resources, to even more dire predictions by May 1920 from David White, chief geologist at the USGS, that oil production would peak "probably within five years and possibly in three years." (In fact, new oil discoveries quickly brought the price of oil down after 1920.)

All of these events - World War, the influenza epidemic, the race riots, the Big Red Scare, the oil shock - were associated with hugely unsettling narratives that could have led to a sense of economic uncertainty that might have discouraged discretionary spending of households and slowed down hiring 
decisions of firms around the world. These certainly sound like more significant potential causes than New York Fed President Benjamin Strong's decision to take a cruise when he was needed.

There were also more subtle narratives that might have brought on the recession. A story was afloat in 1920 that the consumer price index would eventually come back down to its level in 1913, just before

World War I. Not everyone expected this of course, but, obviously, with such deflation expectations, many would think one should wait to buy until prices fell, but large numbers of people waiting to buy brought on a depression. For those with such deflation expectations, the expected real interest rate was super high. Not a single newspaper represented by ProQuest News \& Newspapers made any reference at all to real interest rates during this depression, even though the concept of the real interest rate had been introduced to economists by John Bates Clark (1895). The concept of real interest rate just had not gone viral yet (and you might say it still hasn't). But many people certainly understood why they should postpone buying and avoid borrowing when massive deflation is expected.

In 1913 in the U.S., a retail price index, predecessor to the Consumer Price Index (CPI), attracted great attention. The CPI that we have now began with a base value of 10 in 1913 . By 1920, the index had doubled to 20 , and by mid-1921 it had fallen to 17 . The price increase between the end of the war and 1920 was widely blamed on people who were labeled with the newly-popular word "profiteer.” The Oxford English Dictionary gives first use of the word profiteer as occurring in 1912, but its use did not take off until late in World War I and after. None of the usual synonyms for profiteer (racketeer, exploiter, black marketer, bloodsucker, vampire) seem to have the same meaning and association with wartime fortune building at the expense of war heroes. The word is a play on the much older word privateer, meaning a pirate who has the support of a hostile government. Wartime narratives spread of customers angry at high prices chastising their milkmen and telling their butcher they would stop eating meat altogether to spite them. But the narrative epidemic was unfazed by the end of the war. 
The popular author Henry Hazlitt wrote in 1920:

"Hence we have self-righteous individuals on every corner denouncing the outrages and robberies committed by a sordid world. The butcher is amazed at the profiteering of the man who sells him shoes; the shoe salesman is astounded at the effrontery of the theatre ticket speculator; the theatre ticket speculator is staggered at the high-handedness of his landlord; the landlord raises his hands to high heaven at the demands of his coal man, and the coal man collapses at the prices of the butcher." ${ }^{20}$

U. S. Senator Arthur Capper was reported in January 1920 as saying "Profiteers are more

dangerous than Reds" and urged consumers to "boycott the profit hogs by refusing to buy goods offered at extortionate prices." ${ }^{21}$ Perhaps the 1920-21 recession might better be thought of as the 1920-21 consumer boycott.

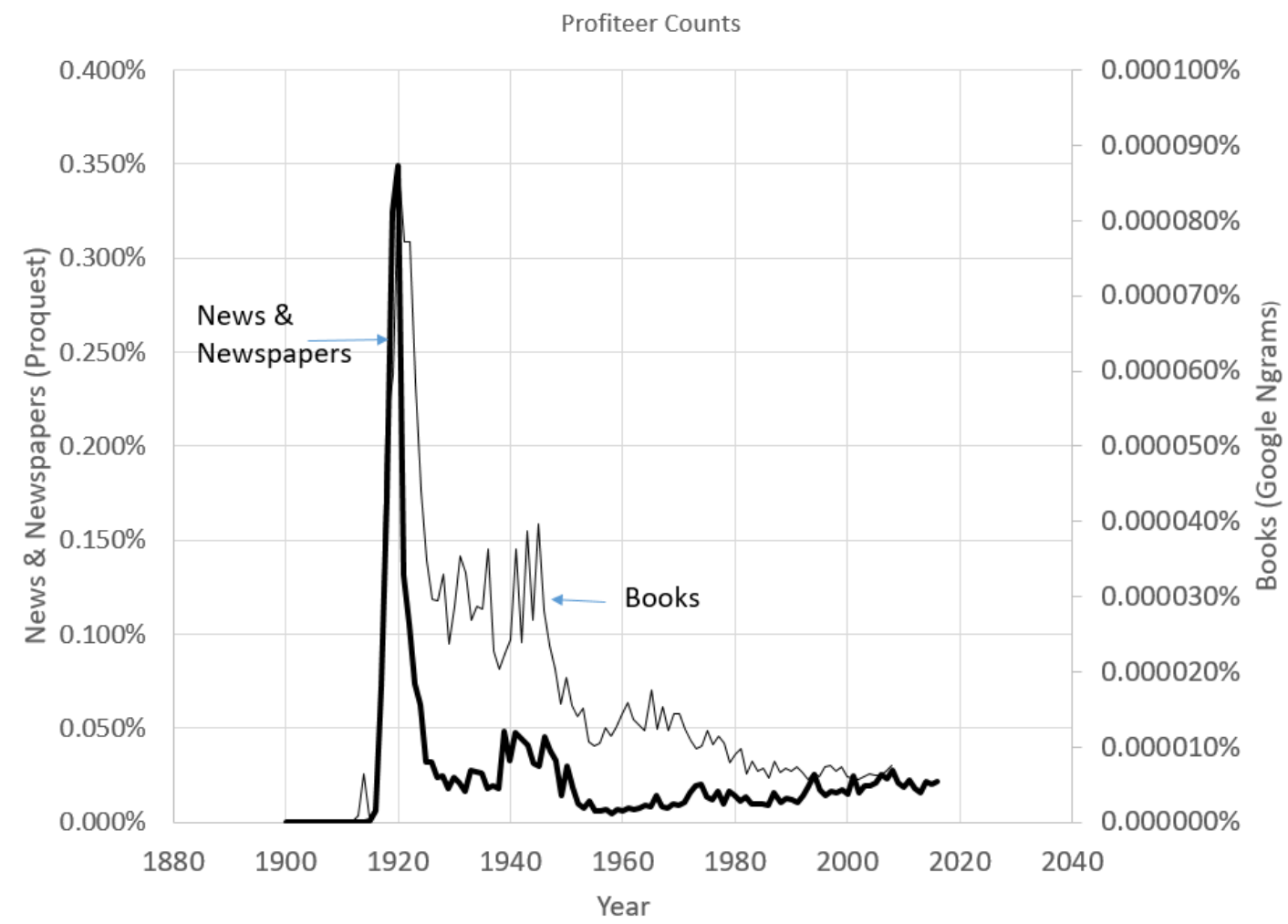

Figure 5. Frequency of appearance of word "profiteer" by year. For news and newspapers (1900-2016, from ProQuest) it is the number of articles with this phrase as a percent of all articles that year. For books (1900-2008, from Google Ngrams) it is the number of occurrences of the phrase divided by the total number of words in the database for that year, in percent.

\footnotetext{
${ }^{20}$ Henry Hazlitt, "Profiteers as Public Benefactors," New York Times, March 21, 1920, p. xxx10.

${ }_{21}^{21}$ "Profiteers are Incubators for 'Reds'-Capper," Chicago Daily Tribune Jan 25, 1920, p. A9.
} 
But it wasn't just anger at profiteers that curtailed consumption. The story that consumer prices would fall dramatically, a story which had good contagion since it was associated with the profiteer narrative, was not so much told as intimated thousands of times during the 1920-21 recession when newspapers heralded some individual prices that had indeed fallen to 1913 or 1914 levels. This is typical newspaper reporting, with writers attempting to make an otherwise marginally interesting story engaging to general readers. The newspapers knew that at a time of deflation, readers were responsive to such stories because to the untrained mind, it seemed natural that once the war was over, prices would return to their old levels: very important to someone trying to decide whether to buy a new house or car.

Waiting to buy discretionary items until the prices fell seemed an obvious strategy to many, but doing so brought on a depression. As one observer wrote in 1920: "The buying public knows that the war is over and has reached the point where it refuses to pay war prices for articles. Goods do not move, for people simply will not buy." ${ }^{22}$ There was populist anger and protests against profiteering manufacturers and retailers. The protests took on moral dimensions: "If people determine to buy foodstuffs or anything else only what they actually cannot do without, the working of the inexorable law of supply and demand will operate automatically to bring conditions to a more normal state. ${ }^{{ }^{23}}$ Thrift became a new virtue. This 1913 standard was framed as a magical number. In January 1920 the Commissioner of Labor Statistics, Royal Meeker, noted that his agency had started its retail price index in 1913 - a date many believed to be a grounding point for the price level which would lead them to delay purchases: "The prices we kicked about in 1913 have come to be regarded as ideal” but he said that that was a mistaken ideal.

Apparently, his words did not have immediate impact, and people did indeed hold off buying, out of both anger at the narratives of selfish profiteers and the perceived opportunity to profit from postponing

\footnotetext{
${ }_{22}^{22}$ "General Drop in Prices Forecast: Bankers and Traders Expect a Material Reduction in Practically All Lines-Say Era of Extravagance Has Passed.” The Christian Science Monitor Sept 25, 1920, p. 4.

${ }^{23}$ "Women Fight High Prices," The Globe Sept 4, 1920. p. 6.
} 
their purchases during a time of falling prices. Both reasons had emotional resonance as the affect heuristic would predict, in the wake of the war, the influenza epidemic, and other factors.

There we have it: a possible narrative-based unconventional explanation - or at least partial explanation - for the Depression of 1920-21: substantially a consumer boycott against imagined profiteers, based on narratives that made them villains, abetted by a sense of possible personal opportunity to postpone buying, or sense of revenge against the profiteers by outsmarting them, in the presence of an affect heuristic event driven by other emotion-laden narratives (connected to the World War, the Communist revolution, the influenza epidemic, the race riots, the Big Red Scare, the oil shock). Betting on falling consumer prices is a speculative bet that can come to an end just as quickly as opinions about the stock market change, and in this case, the end came in a little over a year.

\section{Narratives during the Great Depression of the 1930s}

The Great Depression (which I describe as the whole period 1929 to 1941, including the two NBER contractions) is the most long-term severe episode of macroeconomic malfunction in world history. And yet we have no received theory why it had such magnitude and duration.

Some theories of the extreme persistence of the Great Depression not relying on narratives seem plausible. Cole and Ohanian (2004) argued that a policy intended to combat the Depression in the United States, embodied in the 1934 National Industrial Recovery Act, which imposed “codes of fair competition”, prolonged the Depression. The Act made it easier for businesses to form cartels and more difficult for them to cut wages. Although the Supreme Court declared the Act unconstitutional in 1935, Cole and Ohanian argue that the Roosevelt administration was able to keep the substance of the codes going anyway.

Eichengreen (1996) and Eichengreen and Temin (2000) have argued that the persistence of the Great Depression has something to do with an unthinking national commitment to the gold standard, as if it 
were some kind of God-given virtue, despite changes in labor markets that made wages more downwardly rigid. They show that countries which abandoned the gold standard earlier showed better recoveries.

Milton Friedman and Anna J. Schwartz in their Monetary History of the United States, blamed the Great Depression on the Federal Reserve, saying that it was explained by variations in the money supply. It was this book that coined the term "quasi-controlled experiment," anticipating the large number of papers we now have under the rubric of "natural experiment”, but the authors didn't have any such claims at this point. Peter Temin put Friedman and Schwartz in a better perspective. The declines in the money supply were mostly endogenous, triggered in part by a series of bank runs, caused by the same feedback that created the Great Depression, and Friedman and Schwartz were really saying nothing more than that the Fed would have done better if they had offset these declines. Temin also observed that Friedman and Schwartz indicated no substantial correspondence between the bank runs and measures of economic activity.

Once again, I argue that most likely a multiplicity of factors, whose confluence produced such severity, caused people to cut back substantially on their expenditures, and these factors in turn often have the form of epidemics of narratives.

The first narrative of the Great Depression was that of the stock market drop on October 28, 1929. This narrative was especially powerful, in its suddenness and severity, focusing public attention on a crash as never before in America. These were record one-day drops. But, beyond the record size, it is hard to say what made this crash narrative such a success. There was something timed very well about this story, that caused an immediate and lasting public reaction. 


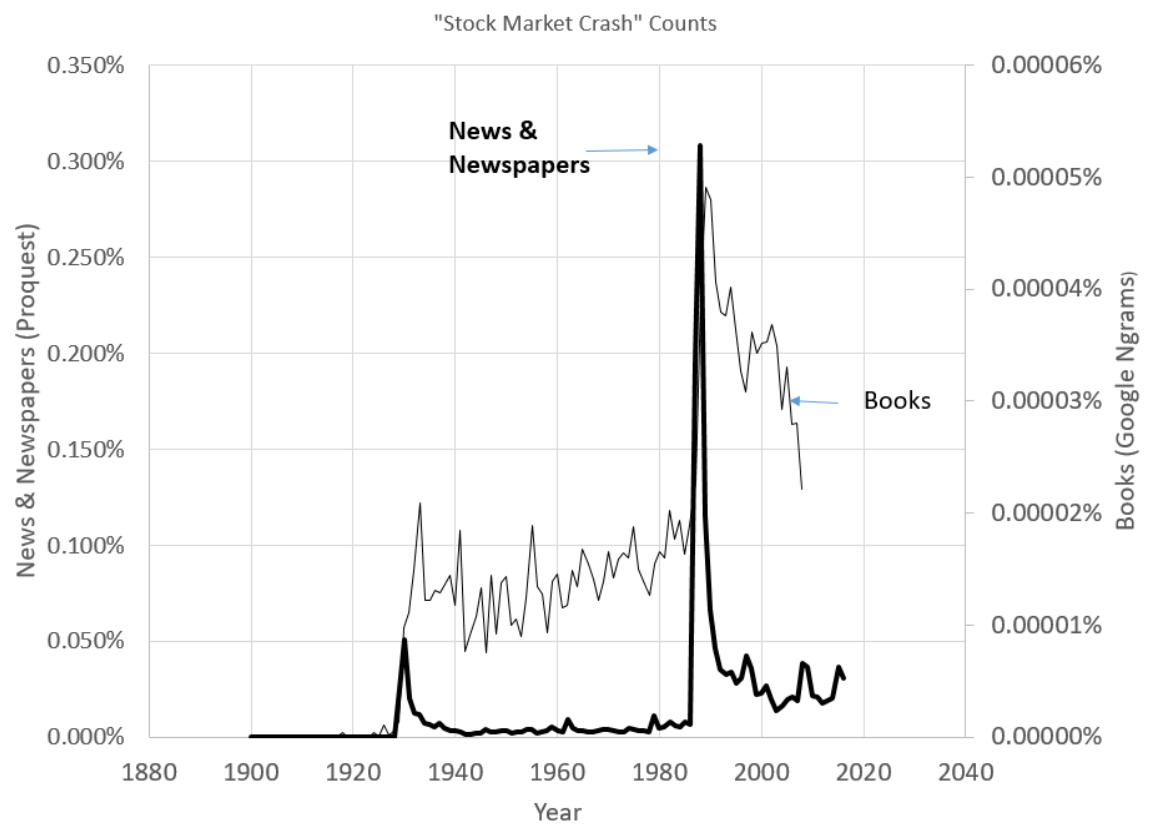

Figure 6. Frequency of appearance of phrase "stock market crash" by year. For news and newspapers (1900-2016, from ProQuest) it is the number of articles with this phrase as a percent of all articles that year. For books (1900-2008, from Google Ngrams) it is the number of occurrences of the phrase divided by the total number of words in the database for that year, in percent.

The narrative of the crash of 1929 was so strong that it persists today, see Figure 6, though more in books than in newspapers. The epidemic actually seems to have begun weakly in 1926, before the actual crash of 1929. In newspapers, there have been two fast epidemics, each peaking within a year, implying very strong sort-run contagion. The first assumed massive proportions in 1929 with the record $12.8 \%$ one-day drop in the Dow Jones Industrial Average on October 28, 1929. The second started on October 19, 1987, when the Dow had a 22.6\% drop, almost doubling the October 28, 1929 drop, though falling short of the two-day drop in 1929. It may seem odd that no other stock price movement merited being called a crash since 1929. Newspapers are very focused on records, presumably because they know their readers are, and 1987 was the only record one-day drop after 1929. Folklore suggests that the stock market epidemic had extremely high contagion in 1929. We know there was high contagion in 1987. In my own mail questionnaire survey in the days following October 19, 1987, I asked when the respondent learned of the 
1987 crash. $97 \%$ of respondents said they learned of it that day, and most of them by midday, meaning neither from morning news or evening news, but presumably largely from word of mouth (Shiller 1989). The 1987 epidemic looks far stronger than the 1929 one, but it certainly draws its strength from memories of 1929, and it may not in fact have been stronger, despite the appearance in Figure 6, given the limitations of word counts as measures of narratives.

Where did the 1929 crash narrative get such strength? Part of the strength in 1929 seems to come from certain moralizing. The fact that the 1920s had been not only a time of economic superabundance but also of sexual liberation - a morality viewed negatively by some, though they were unable to make a case against it until the new story of the stock market crash appeared.

Sermons preached on the Sunday after the crash, November 3, 2016, as reported in newspapers the following day, took great note of the crash, and attributed it to excesses, moral and spiritual. The sermons helped frame a narrative of a sort of day-of-judgment on the "Roaring Twenties." (Google Ngrams shows that the term "roaring twenties" was rarely used in the twenties: the usage of that term first became substantial in the 1930s and follows a hump-shaped pattern roughly like the infectives plot in Figure 2, not peaking until the early 1960 s.)

It helps to listen to these people's narratives from the time of the Great Depression in their own words, R. G. D. Allen in Only Yesterday, 1931, spoke of a more modest countenance:

“...striking alterations in the national temper and ways of American life... One could hardly walk a block in any American City or town without noticing some of them." ${ }^{24}$

Rita Weiman, an author and actress, described the change too, in 1932:

"During those years of inflation, when we were right on the edge of a precipice all the time, we lost our sense of perspective. We spent fabulous sums for objects and pleasures out of all proportion to the value received. If it cost a great deal of money, we promptly came to the conclusion that they must be good....Take the matter of home entertainment. Many of us had almost forgotten how much fun it can be to gather friends around one's own table. Any number of us suffered from 'restaurant digestion.", ${ }_{25}$

\footnotetext{
${ }^{24}$ Allen [1931] p. 289.

${ }^{25}$ Bird, Carol. “We're getting ‘ANCHORED’ Again Says Rita Weiman.” Washington Post. July 10, 1032, p. SM3
} 
Catherine Hackett, another writer in 1932, explained her view of the new morality in the Great Depression:

"In the old Boom era I could buy a jar of bath salts or an extra pair of evening slippers without an uncomfortable consciousness of the poor who lacked the necessities of life. I could always reflect happily on the much-publicized day laborers who wore silk shirts and rode to their work in Fords. Now it was different. The Joneses were considered to be callous to human misery if they continued to give big parties and wear fine clothes." ${ }^{26}$

Another narrative at the beginning of the Great Depression was that of a repeat of the 1920-21 event - no more distant in their memories than the events of 2007-9 are to our memories today. Since many must have expected prices to fall, as they did before in 1920-21, they would want to delay their purchases until the price decline was complete. Economists naturally expected the contraction to be as short lived as in 1920-21, which helps explain why President Hoover and others confidently explained that it would be over soon. But the public didn’t necessarily believe President Hoover. Catherine Hackett wrote:

"I have read enough predictions by economists to convince me that my guess is as good as anyone's on the future trend of prices. A housewife plays the falling commodity market just as an investor plays the falling stock market; she sits tight and waits for prices to settle before buying anything but actual necessities. But I do not need to be an economist to realize that if all the twenty million housewives do that, business recovery will be indefinitely delayed." ${ }^{27}$

I have displayed this quote here as originally worded in 1932 because it illustrates some aspects of consumer behavior then that may not be remembered and appreciated. She finds similarity in consumer behavior to the behavior of stock market speculators, who put their own emotional energy into forming their own personal forecast for the individual stock prices, not trusting experts, as well as the high contagion of narratives about such speculation. Women must have been talking like speculators, telling stories about some smart decisions and some mistakes with their shopping successes and failures. This must often have been about the second moment of consumer price changes. Even if average expectations for inflation were

\footnotetext{
${ }^{26}$ Hackett, Catherine. "Why We Women Won’t Buy.” Forum and Century. December 1932, p. 343.

${ }^{27}$ Hackett 1932 op. cit.
} 
nonnegative, it is plausible if there was a higher contagion rate for emotionally-laden narratives about the price decline scenario, there could be significant net decrement to consumer spending.

It is curious that economists haven't looked more at testimonies of women to understand the consumption function. Even when, maybe especially when, prices are rising rapidly, women must have been talking extensively about strategizing their shopping around their hunches. Apparently then, especially as sex roles were more strongly divided than they are today, it was men's business to play the stock market and women's business to manage the shopping, except perhaps around 1929 when women were notoriously getting into the stock market speculation game. ${ }^{28}$

So, there were attempts again to create a moral imperative against betting on falling prices, against women's behavior that was analogous to that of the generally male short sellers on the stock market. The Washington D.C. Chamber of Commerce launched a campaign in 1930 with the slogan "Buy Now for Prosperity." A "Prosperity Committee” sought the participation of clergymen of all denominations to "preach prosperity through their pulpits" and thereby to "stimulate production, relieving the unemployment situation." ${ }^{29}$

In 1932, the depths of the Depression, a Mrs. Charles E. Foster reportedly told a women's group:

"One of the most effective weapons in the hands of American women today is their tremendous purchasing power. We are told that they spend eighty-five percent of the incomes of the United States. How could they better create public opinion in favor of spending as usual than by setting the example themselves?”30

Even as it happened, the contraction was thought of popularly as the product of some kind of

feedback. In his 1933 inaugural address, President Franklin Delano Roosevelt summed it up with the words "the only thing to fear is fear itself," describing people as responding with fear to others' fear. This quote is

\footnotetext{
${ }^{28}$ John Jacob Raskob. 1929. "Everybody Ought to Get Rich.” Ladies Home Journal.

${ }^{20 " B u y-N o w ~ C a m p a i g n ~ S t a r t e d ~ i n ~ C a p i t a l, " ~ T h e ~ W a s h i n g t o n ~ P o s t, ~ O c t ~ 25, ~ 1930, ~ p . ~} 7$.

so“"Jersey Clubwomen Urged to Arouse Public Opinion in Favor of Spending” New York Herald Tribune, Feb 7, 1932, p. E11.
} 
widely remembered today; his fireside chat has developed into a powerful slow narrative, in contrast to Hackett's, which does not quite describe an emotion of fear.

Roosevelt also offered moral reasons to spend. Days after his inauguration in 1933, President Roosevelt took the unusual step of addressing the nation on the radio at a time of a massive national bank run that had necessitated shutting all the banks down. In this "fireside chat" he explained the banking crisis and asked people not to continue their demands on banks. He spoke to the nation as a military commander would speak to his troops before a battle, asking for their courage and selflessness. Roosevelt asserted "You people must have faith. You must not be stampeded by rumors or guesses. Let us unite in banishing fear." ${ }^{31}$ His personal request to the nation stuck: it ended the bank run, money flowed into, not out of, the banks when they were reopened. The narrative of this first fireside chat is still with us today, and every president starting with President Ronald Reagan has offered regular chats on the radio on Saturdays, but the narrative has not been powerful enough, or not used well enough, to prevent recessions.

The macro storyline in the Great Depression gradually morphed into a national revulsion against the excesses and pathological confidence of the Roaring Twenties. Other narratives focused on the rising leftist or Communist movement that was seen as potentially influencing future government policy far beyond the National Industrial Recovery Act (NIRA), the new deal institution to support fair prices. The NIRA was perceived as only one example of the interference with business that might come eventually.

The worst days of the Great Depression, in 1932 and 1933, were haunted by scary narratives coming from Europe and Asia. Japan had just occupied Manchuria in 1931. In the Soviet Union in 193233, The Holodomor, the ethnic-Ukrainian version of the Holocaust, was raging in the form of a man-made famine - Stalin's attempt to stifle dissent which cost millions of lives. These narratives, with hindsight sounding like some of the worst narratives of World War II to come, were widely circulated in the West. In

\footnotetext{
${ }^{31}$ Roosevelt Fireside Chat No. 1 March 12, 1933 https:/www.youtube.com/watch?v=r6nYKRLOFWg
} 
January 1933, Hitler seized power in Germany and quickly began murdering his political opponents and terrorizing Jews.

These narratives were good reasons for anxiety that might encourage many to cancel their plans for frivolous spending: a larger house or a new car, in order to feel they had sufficient savings. Some of these events also brought moral reasons not to spend. There were many boycotts: against German and Japanese goods as well as against goods associated with Jewish people. Germans began boycotting western goods. These actions must have had some economic effect.

Franklin Allen's 1931 book, Only Yesterday, seemed to get closer to understanding the real cause of the Great Depression, in terms of the stories of the time, and the book has motivated my thinking ever since I first read it. The book may seem superficial in a sense: just a collection of stories with no organizing theme except at the end. However, through understanding all those stories of fads and crazes, one gets a view of what was happening in the 1920s. One reviewer of Allen's book in 1931 explained what he learned from the book: "Of course, we change fads. That is the essence of our changelessness - that we plunge from one craze to another with kaleidoscopic ease. ${ }^{32}$

Contagion rates for stories of business failures, rather than inspirational stories, were naturally high at a time when a large fraction of the population were unemployed. Stories abounded of business people committing suicide. ${ }^{33}$

It seemed to most people in the late depression that there was an inevitable trend towards government control of business. A May 1939 poll asked, "Do you think that ten years from now there will be more government control of business than there is now or less government control of business?" $56 \%$ of the respondents said more; 22\% less; 8\% neither; 14\% had no opinion (Higgs 1997).

\footnotetext{
${ }^{32}$ Lewis Gannett, "Books \& Things,” New York Herald Tribune, Dec 1, 1931 p. 19.

"33" Rise in Suicide Rate Laid to Depression: National Survey Shows 20.5 of 100,000 People Took Their Lives in 1931Highest Figure since 1915, New York Times, June 23, 1939, p. 24.
} 
By the 1930s, the theory that Communist forces in America were massing forces into an inevitable future direction for America was a story everyone knew, whether they liked it or not. The increasing radicalization of President Roosevelt plays a part in these stories: in 1936, speaking of the magnates of organized money, he said "I welcome their hatred." (Higgs 1997).

The Communist conspiracy narrative, from the late 1930s, included anecdotes about increasingly leftist labor laws stymying business. Stories circulated of outside-agitator unions disrupting peaceful companies whose employees were happy with their jobs; of strangers picketing and coordinated refusals of other unions to handle the company's products; of the existing employees forming their own union to try to stave off the attack, and the radical National Labor Relations Board throwing it out as a "company union." ${ }^{34}$

One of the stories that was circulating in the United States during the Great Depression was that of Lázaro Cárdenas, the president of Mexico, 1934-40. Just as in the United States, the Depression amplified calls for socialist or communist solutions in Mexico, which put fear in the hearts of businesspeople. Cárdenas expropriated land from the commercial haciendas and in 1938 nationalized the Mexican oil industry and railroads. These actions were seen as a model for what might happen in other countries, and indeed nationalizations in other countries did follow Cárdenas' example, though not in the United States.

A huge rise in policy uncertainty in both the U.S. and the U.K. was revealed by the Economic Policy Uncertainty Index of Scott R. Baker, Nicholas Bloom, and Steven J. Davis, which is based on counts of words in online news media.

\footnotetext{
${ }^{34}$ Harold Fleming. "No New Deal Agency Irks Businessmen like the NLRB” The Christian Science Monitor, August 23, 1939.
} 


\section{Narratives Leading Up to the "Great Recession" 2007-9}

The 2007-9 world financial crisis has been called the "Great Recession" as a reference to the "Great Depression” of the 1930s. Certainly, the narrative of the Great Depression was suddenly thrust into the national attention as never before, not since the 1930s, see Figure 7.

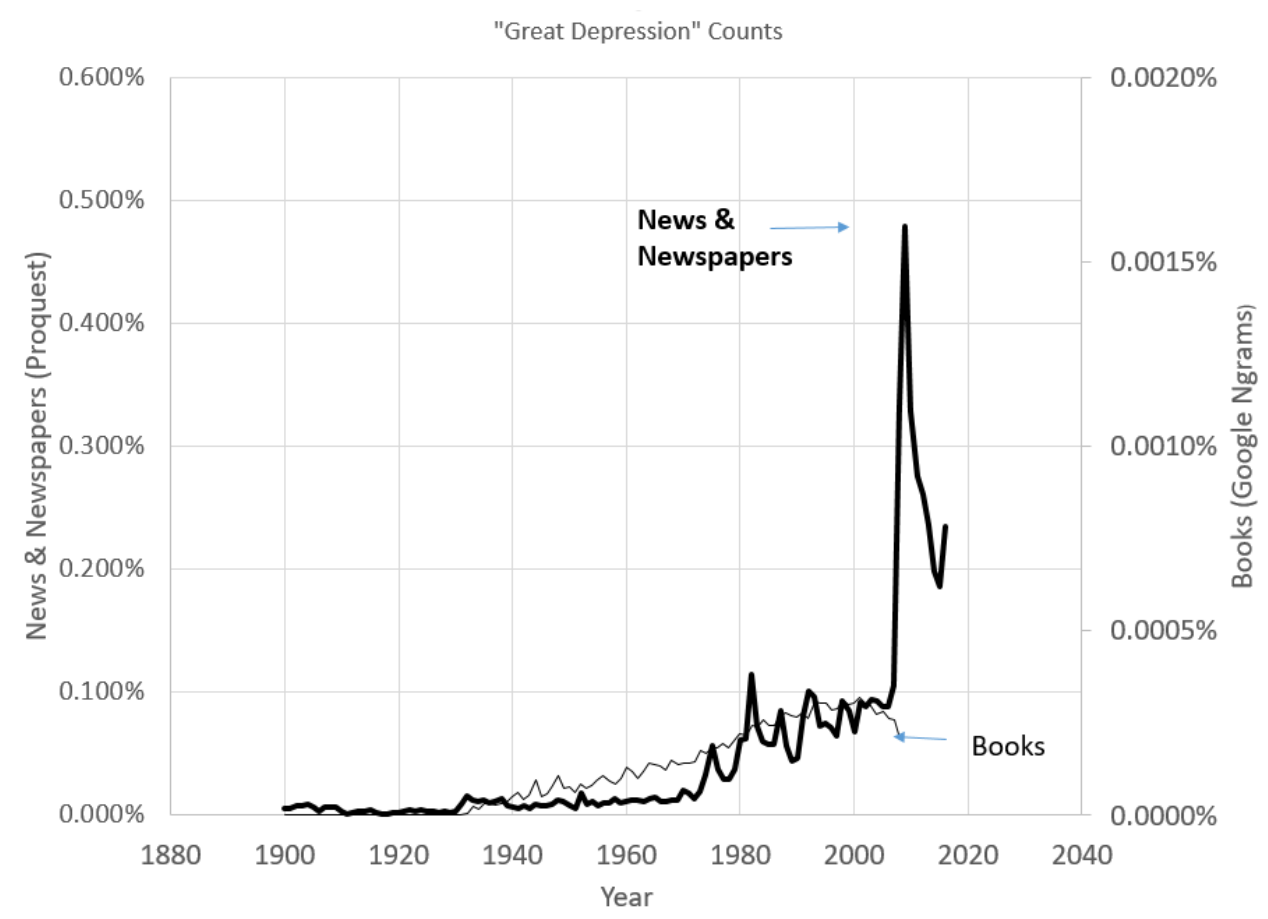

Figure 7. Frequency of appearance of phrase "Great Depression" by year. For news and newspapers (19002016, from ProQuest) it is the number of articles with this phrase as a percent of all articles that year. For books (1900-2008, from Google Ngrams) it is the number of occurrences of the phrase (capitalized) divided by the total number of words in the database for that year, in percent.

The figure suggests far more attention was paid in 2009 to the Great Depression than during the

Great Depression itself, though one must be careful to understand that people hadn't really named it the

Great Depression yet as it happened. They certainly had Depression-linked narratives, associated with 
words unusual to that period, such as breadline, a word that Google Ngrams shows grew rapidly in use in books from 1929 to 1934, and decayed fairly steadily ever since.

The interest in the Great Depression in 2009 is confirmed in Google Trends search counts as well, though not as dramatically as in Figure 7. This does not mean that people were suddenly more interested in Franklin Roosevelt or The New Deal. Counts show virtually no increase in interest in these details of history. It was more just a quick and easy way to communicate narrative: we have passed, by 2007, a euphoric speculative immoral period like the Roaring Twenties, the stock market and banks are collapsing in 2008 as around 1929, and now the economy might really collapse again like that; we might even be unemployed and on the street crowding around failed banks, yes really! End of basic narrative.

Consider a narrative-based chronology of the 2007-9 financial crisis. Financial crises are driven by a cadence of stories. For example, stories about bank runs were in the $19^{\text {th }}$ century virtually synonymous with financial crises. But after the Great Depression bank runs were thought to be cured. The Northern Rock bank run in 2007, the first U.K. bank run since 1866, brought back the old narratives of panicked depositors forming angry crowds outside closed banks. The story led to a skittishness internationally, and to the Washington Mutual (WaMu) bank run a year later in the U.S., and, then, the Reserve Prime Fund run a few days after that in 2008. These events then led to the very unconventional U.S. government guarantee of all U.S. money market funds for a year. Apparently, governments were aware that they could not let the old story of a bank run go live over concern for its effects on public anxiety.

A narrative approach to understanding the crisis might take us back further in time. In 2001, the U.K. television show "Property Ladder" was launched. This reality TV show which depicted individuals buying homes, fixing and prettifying them a little, and then reselling them at a large profit, was a big success. Successful narratives are copied with appropriate changes and launched anew in other countries. The U.S. TV show "Flip that House" attempted to replicate Property Ladder in 2005, but it was canceled at the time 
of the financial crisis in 2008. Property Ladder lasted until 2009, renaming itself Property Snakes and Ladders, until its demise later that year.

Leading up to the Great Recession 2007-9, and setting the stage for it, were widespread fears of long-term job insecurity because of advancing technology. Facebook and Gmail appeared in 2004,

YouTube in 2005, Twitter in 2006, and the I-Phone in 2007. These were the prominent business stories of the time, and they may have left the impression that the companies that were forming might not be creating jobs for those not technologically gifted or connected with other such people.

The very name "Great Recession" could be interpreted as evidence of a narrative epidemic. Naming the financial crisis after the Great Depression was not the choice of any one individual. There had been earlier attempts to attach the name "Great Recession" to preceding recessions. Otto Eckstein wrote a book entitled The Great Recession in 1978 that attempted to attach this name to the severe 1974-75 recession. However, the name did not stick. Again in the 1981-82 recession this term was used by Joseph Granville, the flamboyant analyst who stirred much talk about his prediction of stock market drops by engaging in stunts such as appearing at events with a trained chimpanzee. ${ }^{35}$ But again, the name did not go viral. It was different, however, in 2007-9. Nouriel Roubini first referred to the "Great Recession of 2007" in late 2006, a year before the recession had started. ${ }^{36}$ But it took several more years, until 2009, for the term to catch on and go viral.

The Great Depression of the 1930s has long been associated in the public mind with the "stock market crash of 1929" that preceded it. Most people appear to be wary of attaching grandiose names to events, unless there is authority justifying that. Lionel Robbins was successful with his book title, The Great Depression in 1934 because President Roosevelt, a generally recognized authority, had used the words ${ }^{37}$, suggesting the worst economic contraction ever. It is conceivable that naming the event thus might have

\footnotetext{
${ }_{25}^{25}$ "Granville: Market Heading for another 'Massacre”" The Atlanta Constitution, January 1, 1982, p. 2C.

${ }^{36} \mathrm{http}: / /$ search.proquest.com/news/docview/222625882/EE9DE487B6184667PQ/1?accountid=15172

${ }^{37}$ Franklin Delano Roosevelt, during his first election campaign, September 20, 1932, "how heavily the hand of the great depression has fallen upon this Western country" (transcript in New York Herald Tribune, Sept 21, 1932. p. 6.
} 
been a self-fulfilling prophecy in that it created worries and uncertainty, perhaps contributing to the persistence of a depressed economy.

What is it about the 2007-9 event that made the name "Great Recession" suddenly contagious? Judging from the peak U.S. unemployment rate, it was less severe than the 1981-2 recession.

Perhaps it was because the 2007-9 event fit the most generic and ill-informed memories of the Great Depression. People remember massive bank failures as part of the Great Depression story, and that was a better fit, it appeared, with the events of 2007. In the 1981-82 recession the stock market had not been booming (it had never recovered from the 1974-5 crash, which still seemed like a recent major event in 1981), and the stock market did not fall below its 1980 value by 1982. In contrast, 2007-9 saw a near halving of the market from very high levels. People in 1981-82 were, as public opinion polls confirm, preoccupied with out-of-control consumer-price inflation, and saw the events in terms of a suddenly strong central bank effort to contain the inflation.

Psychologists Daniel Kahneman and Amos Tversky's representativeness heuristic is the principle that people judge current events by their similarity to memories of representative events. The Great Depression was a model that is exaggerated in people's minds because of its legendary status. In 2007-09 presidents and prime ministers invoked parallels to the Great Depression to justify their requests to apply stimulus. Did this contribute to a self-fulfilling prophecy, a mirror event to the Great Depression, albeit not as severe? Indeed, the name says it all, the Great Recession, not quite the Great Depression.

\section{Narratives in 2017 and the Outlook for the Economy Today}

The narratives from the 2007-2009 financial crisis have faded in our memories, but are still alive and still relevant. But, for now, the U.S. national attention has shifted quite dramatically away from that mode of thought. 
President-elect Donald J. Trump is a master of narratives. His narratives have become highly inspirational for some, as was seen by the tens of thousands who came to his campaign rallies. They have become a source of alarm for others.

His remarkable success in the presidential election campaign last year may be attributed to, among other things, his public persona from his lifelong effort to promote himself as a business genius able to make hard decisions and strike deals. An important reason for his contagion is his reality television show, The Apprentice, which focused lavish attention on Trump. That show was such a success that it was copied in numerous other countries each with their own home-grown Trump substitute, some of whom went on to achieve their own political success, notably João Doria, elected mayor of Sao Paulo, Brazil, in $2016 .^{38}$

History does not suggest that even a politician as skilled as Trump can actually control the progression of the narratives he created. The manner in which these narratives unfold will play an important role in any economic forecast. To best predict economic activity, we need, among other things, to watch the narratives and ask: how will the emerging twists in the narratives affect propensity to spend, to start unconventional new businesses, to hire new employees? In short, how will the animal spirits be affected?

Trump’s example and admonition to "think big and live large" (Trump and McIver, 2004) appears to provide inspiration to many of his admirers, and that might well be expected, along with his stimulative tax policy, to boost consumption demand as well as entrepreneurial zeal. Many people might take the Trump story as a script for themselves, and thus spend freely and raise their risk tolerance.

\footnotetext{
${ }^{{ }^{3}}$ BBC, “From The Apprentice to politics: it's not just Trump,” December 10, 2016
} 
But we also have to take into account the Trump detractors, about as many as his admirers, who may be thinking more along the lines of the morality play of the 1930s. Predicting aggregate demand from the new Trump narratives requires some careful attention to conflicting narratives.

Incorporating such factors into economic forecasts is not impossible. We would benefit, however, from more research into understanding the role of narratives in the economy.

\section{Opportunities for Researchers in Narrative Economics}

Narrative economics, to the extent that it has ever been practiced by scholars, has had a poor reputation. In part, it may be due to the fact that the relation between narratives and economic outcomes is likely to be complex and time varying. The impact of narratives on the economy is regularly mentioned in journalistic circles, but without the demands of academic rigor. The impact of journalistic accounts of narratives may have been connected to aggressive forecasts which often proved wrong. But, the advent of big data and of better algorithms of semantic search might bring more credibility to the field.

Research in economics is already on its way to finding better quantitative methods to understand the impact of narratives on the economy. Textual search is a small but expanding area in economic research. A search of the NBER working paper database finds less than one hundred papers with the words “textual analysis.” Textual analysis has been used by economists, for example, to document changes in party affiliation (Kuziemko and Washington, 2015); political polarization (Gentzkow et al. 2016); and news and speculative price movements (Roll 1988; Boudoukh et al. 2013). But much more could be done. The historical analysis could be carried further into databases of personal diaries, sermons, personal letters, psychiatrists' patient notes and social media.

There should be more serious efforts at collecting further time series data on narratives, going beyond the passive collection of others' words, towards experiments that reveal meaning and psychological significance. Since 1989, I have been collecting some such data, on questionnaires about stock prices and 
home prices, with open-ended questions that invite the respondent to write a sentence or two. The questions are designed to stimulate the respondent to think about what is motivating them, so that their responses can be analyzed in posterity. However, I would advocate for there to be resources devoted to collecting data about narratives and public reactions and understandings of narratives on a serious scale. It could be done with focus groups and social media.

But this research still today needs improvement in tracking and quantifying narratives. Researchers have trouble dealing with a set of often-conflicting narratives and gradations and superposition of them. Even the simplest epidemic model shows that no narratives reach everyone, and whom a particular narrative reaches and whom it does not is largely random. The meanings of words depend on context and change through time. The real meaning of a story, which accounts for its virality, may also change through time and is hard to track in the long run.

There are serious issues of inferring causality, distinguishing between narratives that are associated with economic behavior just because they are reporting on the behavior, and narratives that create changes in economic behavior. These issues are not insurmountable. ${ }^{39}$

Researchers have to grapple with issues that have troubled literary theorists. Those theorists who, as noted above, try to list the basic stories in all of literature, have to try to distill what it is that defines these stories, what makes them contagious. There are so very many contagious stories at any time in history, and it is hard to sort through them. The theorists run the risk of focusing on details of the stories that are common just because the events are actually familiar in everyday life. They also face the difficulty of accounting for changes through time in the list of stories.

\footnotetext{
${ }^{39}$ For example, Chen et al. (2016) compute a "propagation score" of narrative contagion based on citations and citations within citations. Such measures relate to the contagion importance of narratives beyond the mere count of numbers of mention.
} 
Research in semantic information and semiotics is advancing. For example, machine translation is already somewhat able to pick which meaning of the word is intended by looking at context, at other adjacent words. Semantic search took a big leap forward in 2010 when Apple, Inc. introduced its Siri function, which allows users to verbally ask a question like "What is the longest river in South Africa?" and receive a direct verbal answer. Semantic search is now getting well established around the world.

Semantic search may, however, take a long time to reach the abilities of the human mind to understand narratives. In the meantime, researchers can still be quantitative in the study of narratives if they use multiple research assistants with explicit instructions to read narratives and to classify and quantify them for their essential emotional driving force. Advances in psychology, neuroscience, and artificial intelligence may be relied on to improve our sense of structure in narrative economics.

As research methods advance, and as more social media data accumulate, textual analysis will be a stronger field in economics in coming years. It may allow us to move beyond 1930s-style models of feedback, the "multiple rounds of expenditure," and get closer to all the kinds of feedback that really drive economic events. And it will help us to better understand the kinds of deliberate manipulations and deceptions we have been suffering under, and to formulate some positive economic policies that take into account the background of narratives. 


\section{References}

Akerlof, George A. 2007. "The Missing Motivation in Macroeconomics” (AEA Presidential Address) American Economic Review. 97(1):3-36

Akerlof, George A. and Rachel Kranton. 2011. Identity Economics: How Our Identities Shape Our Work, Wages and Well-Being. Princeton: Princeton University Press.

Akerlof, George A, and Robert J. Shiller. 2009. Animal Spirits: How Human Psychology Drives the Economy and Why this Matters for Global Capitalism, Princeton: Princeton University Press.

Akerlof, George A, and Robert J. Shiller. 2015. Phishing for Phools: The Economics of Manipulation and Deception. Princeton: Princeton University Press.

American Psychiatric Association. 2013. Diagnostic and Statistical Manual of Mental Disorders Fifth Edition. American Psychiatric Publishing.

Bailey, Michael, Ruiqing Cao, Theresa Kuchler and Johannes Stroebel. 2016. "Social Networks and Housing Markets. Presented at NBER behavioral finance workshop

Banerjee, Abhijit. 1992. “A Simple Model of Herd Behavior.” Quarterly Journal of Economics.

Bartholomew, D. J. 1982. Stochastic Models for Social Processes.

Bauckhage, Christian. 2011. "Insights into Internet Memes.” Proceedings of the Fifth AAAI Conference on Weblogs and Social Media. http://www.aaai.org/ocs/index.php/\%20ICWSM/ICWSM11/paper/viewFile/2757/3304

Beck, Andrew T., Andrew C. Butler, Gregory K. Brown, Katherine K. Dahlsgaard, Cory F. Newman and Judith S. Beck. 2001. "Dysfunctional Beliefs Discriminate Personality Disorders." Behavioral Research and Therapy. 39(10):1213-1225.

Benabou, Roland. 2013. "Groupthink: Collective Delusions in Organizations and Markets." Review of Economic Studies. 80:429-462.

Berger, Jonah. 2013. Contagious: Why Things Catch On. New York: Simon and Schuster.

Berger, Ronald J. and Richard Quinney. 2004. Storytelling Sociology: Narrative as Social Inquiry. Lynne Rienner Publishers.

Boltz, Marilyn. Matthew Schulkind and Suzanne Kantra. 1991. "Effects of Background Music on the Remembering of Filmed Events.” Memory \& Cognition 19(6)593-606.

Booker, Christopher. 2004. The Seven Basic Plots: Why We Tell Stories. New York: Bloomsbury.

Boudoukh, Jacob, Ronen Feldman, Shimon Kogan and Matthew Richardson. 2013. "Which News Moves Stock Prices: A Textual Analysis.” NBER Working Paper No. w18725.

Bramoullé, Yann, Andrea Galeotti, and Brian Rogers, editors. 2016. The Oxford Handbook of the Economics of Networks. Oxford: Oxford University Press.

Brooks, Peter. 1992. Reading for the Plot: Design and Intention in Narrative. Cambridge: Harvard University Press.

Brown, Donald E. 1991. Human Universals. Boston: McGraw-Hill. 
Bruner, Jerome. 1998. What Is a Narrative Fact? The Annals of the American Academy of Political and Social Science 560:17-27.

Cawelti, John G. 1976. Adventure, Mystery, Romance: Formula Stories as Art and Popular Culture. Chicago: University of Chicago Press.

Chandani, Sushil, David Hirshleifer and Ivo Welch. 1992. "A Theory of Fashions, Fads, Customs and Cultural Change as Informational Cascades.” Journal of Political Economy. 100(5):992-1026.

Chen, Daniel Li, Adithya Parthasarathy, and Shivam Verma. 2016. "The Genealogy of Ideology: Predicting Agreement and Persuasive Memes in the U.S. Courts of Appeals.” Unpublished paper, Toulouse School of Economics.

Clark, John Bates. 1895. "The Gold Standard of Currency in the Light of Recent Theory." Political Science Quarterly. 10(3):383-97.

Cole, Harold L. and Lee E. Ohanian. 2004. "New Deal Policies and the Persistence of the Great Depression: A General Equilibrium Analysis.” Journal of Political Economy. 112(4):779-816.

Daley, Daryl J. and David. G. Kendall. 1964. “Epidemics and Rumors.” Nature. 204:1118. 1964.

Daley, Daryl J. and David. G. Kendall. 1965. “Stochastic Rumors.” IMA Journal of Applied Mathematics 1:42:55.

Dawkins, Richard. 1976. The Selfish Gene.

De Long, J. Bradford, Andrei Shleifer, Lawrence H. Summers and Robert J. Waldmann. 1990. "Noise Trader Risk in Financial Markets.” Journal of Political Economy. 98(4):703-738.

Dimand, Robert W. 1988. The Origins of the Keynesian Revolution: The Development of Keynes's Theory of Employment and Output. Stanford: Stanford University Press.

Dohmen, Thomas J., Armin Falk, David Huffman, and Uwe Sunde. 2006. "Seemingly Irrelevant Events Affect Perceptions and Expectations - The FIFA World Cup 2006 as a Natural Experiment." CEPR Discussion Paper No. 5851. https://ssrn.com/abstract $=951789$

Durkheim, Emile. 1897. Suicide.

Eckstein, Otto. 1978. The Great Recession with a Postscript on Stagflation. Elsevier Scientific.

Eichengreen, Barry. 1996. Golden Fetters.

Eichengreen, Barry, and Peter Temin. 2000. "The Gold Standard and the Great Depression," 2000. Contemporary European History. 9(2):183-207, July.

Escalas, Jennifer Edson. 2007. "Self-Referencing and Persuasion: Narrative Transportation versus Analytical Elaboration.” Journal of Consumer Research. 16:421-429.

Fama, Eugene F., and Kenneth R. French. 1993. "Common Risk Factors in the Returns on Stocks and Bonds.” Journal of Financial Economics. 33(1):3-56.

Fehr, Ernst, and Simon Gächter. 2000. "Fairness and Retaliation: The Economics of Reciprocity." The Journal of Economic Perspectives. 14(3):159-81.

Ferrand, Nathalie and Michèle Weil, eds. 2001. Homo Narrativus, Recherches Sur la Topique Romanesque dans les Fictions de Langue Française Avant 1800. Montpellier FR: presses de l’Université Paul Valéry. 
Fisher, Walter R. 1984. "Narration as a Human Communication Paradigm: The Case of Public Moral Argument.” Communication Monographs. 51(1):1-22.

Gentzkow, Matthew, Jesse M. Shapiro and Matt Taddy. 2016. "Measuring Polarization in HighDimensional Data: Method and Application to Congressional Speech.” Unpublished paper, Stanford University.

Gino, Francesca, Michael I. Norton, and Roberto A. Weber. 2016. "Motivated Bayesians: Feeling Moral While Acting Egoistically.” Journal of Economic Perspectives. 30(3):189-212.

Glaeser, Edward L. 2005. "The Political Economy of Hatred.” Quarterly Journal of Economics. 120(1):4586 (February).

Goetzmann, William N., Dasol Kim and Robert J. Shiller. 2016. "Crash Beliefs from Investor Surveys.” Cambridge MA: NBER Working Paper w22143.

Goldin, Claudia. 2014. "A Pollution Theory of Discrimination: Male and Female Differences in Occupations and Earnings.” In Leah Platt Boustan, Carola Frydman, and Robert A. Margo, editors, Human Capital in History: The American Record. Chicago: University of Chicago Press.

Gordon, Robert J. 2016. The Rise and Fall of American Growth. Princeton: Princeton University Press.

Gould, Stephen Jay. 1994. "So Near and Yet So Far.” New York Review of Books. October 20.

Graves, Lloyd Milner Graves. 1932. The Great Depression and Beyond. New York: Press of J. D McGuire.

Hamilton, James. 1983. “Oil and the Macroeconomy since World War II.” Journal of Political Economy. 91(2):228-248. April.

Herr, Paul M., Frank R. Kardes and John Kim. 1991. "Effects of Word-of-Mouth and Product-Attribute Information in Persuasion: An Accessibility-Diagnosticity Perspective.” Journal of Consumer Research, 10:454:62. March.

Hicks, John. 1937. “Mr. Keynes and the 'Classics'; A Suggested Interpretation.” Econometrica 5(2):147-59.

Higgs, Robert. 1997, "Regime Uncertainty: Why the Great Depression Lasted So Long and Why Prosperity Resumed After the War,” The Independent Review, 1(4):561-90. Spring. http://www.jstor.org/stable/pdf/24560785.pdf

Hume, David. 1788 (1742). "On the Rise and Progress of the Arts and Sciences" in Essays and Treatises on Several Subjects, Vol. I, London: T. D. Cadell.

Jackson, Matthew O. and Leeat Yariv. 2005. "Diffusion in Social Networks." Économie Publique 16(1):216.

Kahn, Richard F. 1931. "The Relation between Home Investment and Unemployment." Economic Journal. 41(162):173-98.

Kahneman, Daniel, and Amos Tversky. 2000. Choices, Values and Frames. Cambridge: Cambridge University Press.

Kahneman, Daniel, and Amos Tversky. 1973. "On the Psychology of Prediction.” Psychological Review. 80(4):237-51. 
Kermack W. O. and A. G. McKendrick. 1927. "A Contribution to the Mathematical Theory of epidemics." Proceedings of the Royal Society. 115(772):701-21

Keynes, John Maynard. 1936. The General Theory of Employment Interest and Money. London: Palgrave Macmillan.

Kuziemko, Ilyana, and Ebonya Washington. 2015. "Why Did the Democrats Lose the South? Bringing New Data to an Old Debate.” NBER Working Paper No. 21703.

Kydland, Finn E. and Edward C. Prescott. 1982. "Time to Build and Aggregate Fluctuations." Econometrica 50(6):1345-1370.

Laffer, Arthur. 2004. “The Laffer Curve, Past, Present and Future.” Backgrounder, no. 1765. Heritage Foundation.

Lamberson, P. J. 2016. "Diffusion in Networks.” in Bramoullé, Yann, Andrea Galeotti, and Brian Rogers, editors. 2016. The Oxford Handbook of the Economics of Networks. Oxford: Oxford University Press.

Le Bon, Gustave. 1895. Psychologie des foules (The Crowd) Alcan.

Litman, Barry R. 1983. "Predicting Success of Theatrical Movies: An Empirical Study." Journal of Popular Culture. 16(4):159-175.

Machill, Marcel, Sebastian Köhler and Markus Waldhauser. 2007. "The Use of Narrative Structures in Television News" European Journal of Communication. 22(2):185-205.

MacMullen, Ramsay. 2003. Feelings in History: Ancient and Modern. Claremont California: Regina Books.

McCloskey, Dierdre. 2016. “Adam Smith Did Humanomics: So Should We.” Eastern Economic Journal. 42(4):503-13.

McKay, Charles. 1841. Memoirs of Extraordinary Popular Delusions. London: Richard Bentley.

McQuiggan, Scott W., Jonathan P. Rowe, Sunyoung Lee and James C. Lester. 2008. "Story-Based Learning: The Impact of Narrative on Learning Experiences and Outcomes.” In Beverley P. Woolf, Esma Aïmeur, Roger Nkambou and Susanne Lajoie, editors, Intelligent Tutoring Systems, Springer. ISBN: 978-3-540-69130-3 (Print) 978-3-540-69132-7 (Online)

Mirowski, Philip. 1982. "What's Wrong with the Laffer Curve.” Journal of Economic Issues 16(3):1815-28.

Michel, Jean Baptiste, et al. 2011. "Quantitative Analysis of Culture Using Millions of Digitized Books.” Science. 331(6014):176-82.

Mokyr, Joel. 2017. Culture and Growth: The Origins of the Modern Economy . Princeton NJ: Princeton University Press.

Morson, Gary Paul, and Morton Schapiro. 2017. Cents and Sensibility: What Economics Can Learn from the Humanities. Princeton NJ: Princeton University Press.

Myrdal, Gunnar. 1974. "The Case against Romantic Ethnicity.” Center Magazine. 7(4):26-30. 1974.

O'Connor, Patricia E. 2000. Speaking of Crime: Narratives of Prisoners. Lincoln NE: University of Nebraska Press.

Pace-Schott, Edward F. 2013. "Dreaming as a Story-Telling Instinct." Frontiers in Psychology. 4:159. 
Propp, Vladimir. 1984. Theory and History of Folklore. Minneapolis: University of Minnesota Press.

Robbins, Lionel. 1934. The Great Depression. New York: Macmillan.

Roll, Richard. 1988. “Orange Juice and Weather.” American Economic Review. 74(5):861-80.

Romer, Christina, and David Romer. 2004. "A New Measure of Monetary Shocks" American Economic Review.

Saavedra, Javier, Mercedes Cubero and Paul Crawford. 2009. "Incomprehensibility in the Narratives of Individuals with a Diagnosis of Schizophrenia.” Qualitative Health Research. 19(11):1548.

Samuelson, Paul A. 1958. "An Exact Consumption-Loan Model of Interest with or without the Social Contrivance of Money.” Journal of Political Economy. 66(6):467-82.

Samuelson, Paul A. 1939. "Interactions between the Multiplier Analysis and the Principle of Acceleration" Review of Economics and Statistics 21(2):75-78.

Sartre, Jean-Paul. (1938). Nausea. Translated by Robert Baldick. Harmondsworth U.K. Penquin.

Schank, Roger C., and Robert P. Abelson. 1977. Scripts, Plans, Goals and Understanding: An Inquiry into Human Knowledge. Hillsdale NJ: Lawrence Erlbaum Associates.

Shapiro, Matthew D. "How Economic Shocks Affect Spending.” NBER Reporter, 2016(2):11-13.

Shiller, Robert J. 2000, 2005, 2015. Irrational Exuberance. Princeton: Princeton University Press.

Shiller, Robert J. Market Volatility, Cambridge: MIT Press. 1989.

Shleifer, Andrei, and Robert W. Vishny. 1997. "The Limits of Arbitrage.” Journal of Finance. 52(1):35-55.

Slovic, Paul, Finucane, Melissa L., Peters, Ellen and MacGregor, Donald G. 2007. "The Affect Heuristic". European journal of operational research 177(3):1333-1352.

Smith, Adam. 1869. An Inquiry into the Origin and Causes of the Wealth of Nations. Oxford: Clarendon Press.

Slater, M. D., Buller, D. B., Waters, E., Archibeque, M., \& LeBlanc, M. 2003. “A test of conversational and testimonial messages versus didactic presentations of nutrition information. Journal of Nutrition Education Behavior, 35, 255-259.

Summers, Lawrence H. 1986. "Does the Stock Market Rationally Reflect Fundamental Values?” Journal of Finance. 591-601.

Temin, Peter. 1976. Did Monetary Forces Cause the Great Depression? ${ }^{2}$ New York: W. W. Norton.

Temin, Peter. 1989. Lessons from the Great Depression. Cambridge MA: MIT Press.

Thaler, Richard. 2016. "Behavioral Economics: Past, Present and Future.” (AEA Presidential Address) American Economic Review. 106(7):1577-1600.

Thaler, Richard. 2015. Misbehaving: The Making of Behavioral Economics. New York: W. W. Norton.

Tobias, Ronald B. 1999.Twenty Master Plots and How to Build Them. London: Piatkus.

Trump, Donald J. and Meredith McIver. 2004. How to Get Rich. New York: Random House.

Wanniski, Jude. 1978. "Taxes, Revenues and the 'Laffer Curve'.” National Affairs. 
Wanniski, Jude. 1979. The Way the World Works: How Economies Fail and Succeed. Basic Books.

Weber, K., Martin M. M., Members of COMM 401, and Corrigan, M. 2006. "Creating Persuasive Messages Advocating Organ Donation.” Communication Quarterly. 54:67-87.

Young, Kay and Jeffrey Saver. 2001. The Neurology of Narrative. Madison WI: University of Wisconsin Press.

Zhang, Sarah. 2015. "The Pitfalls of Using Google NGRAM to Study Language.” Wired http://www.google.com/s/www.wired.com/2015/10/pitfalls -of-studying-language-with-googlengram/amp/

Zhao, Laijun, Hongxin Cui, Xiaoyan Qiu, Xiaoli Wang and Jiajia Wang. 2013. "SIR Rumor Spreading Model in the New Media Age.” Physica A: Statistical Mechanics and its Applications. 392(4):9951013. 


\section{KEYWORDS:}

economic fluctuations, business cycles, story, meme, epidemic, SIR model, Kermack and McKendrick, multipliers, bubbles, Depression of 1920, profiteer, Great Depression, stock market crash, 2008 financial crisis, post-truth 